
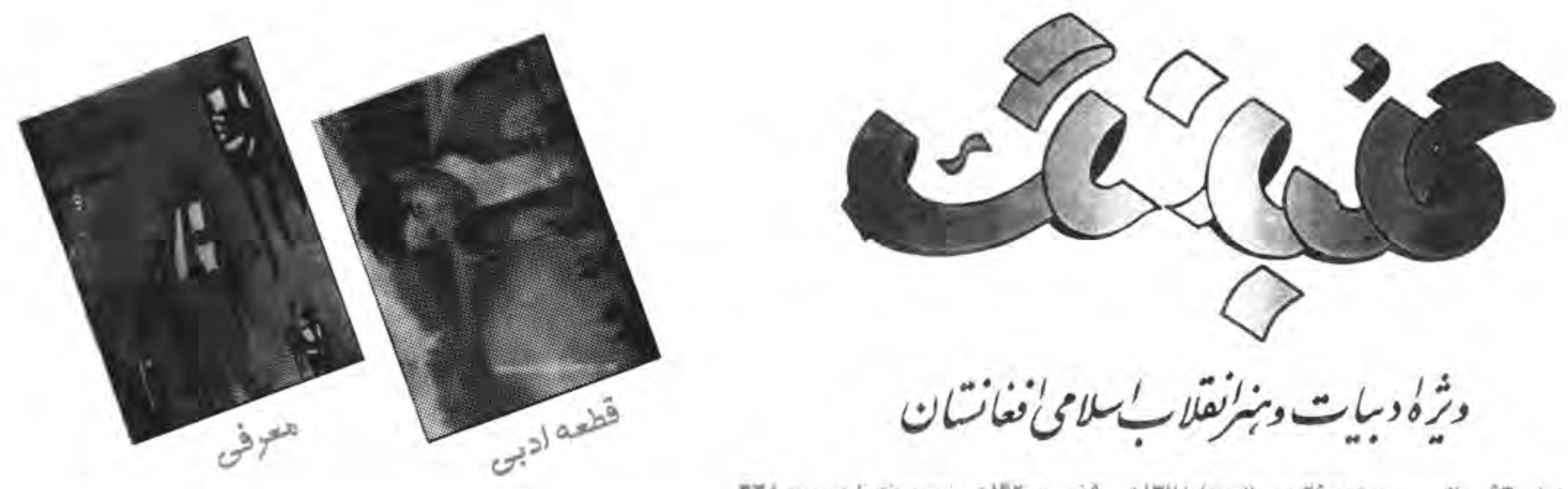

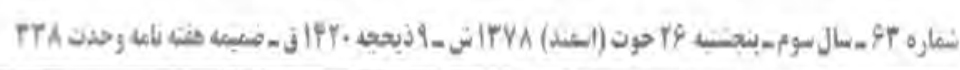

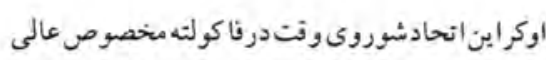

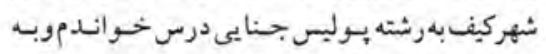

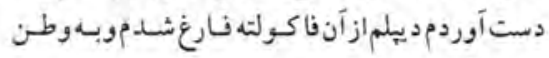
عودتكردم.

o شما از هنر مندانى هستيد كه در

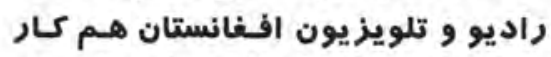

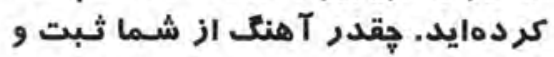

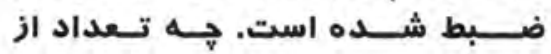

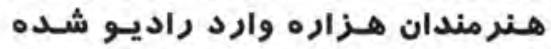

بودند؟

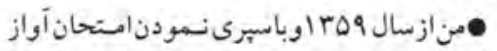

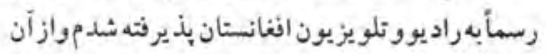

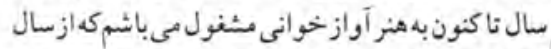

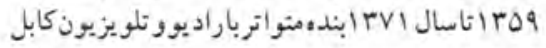

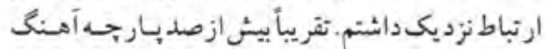

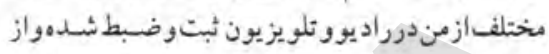

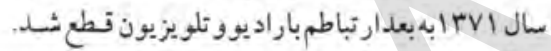

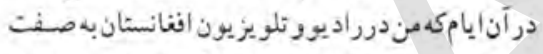

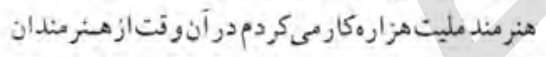

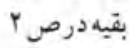

هممدآصفع سلطان زاده

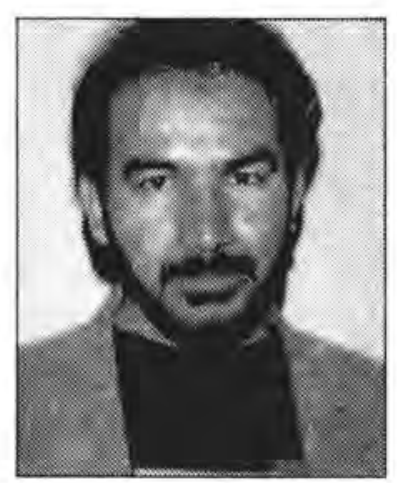
مليك هزارن

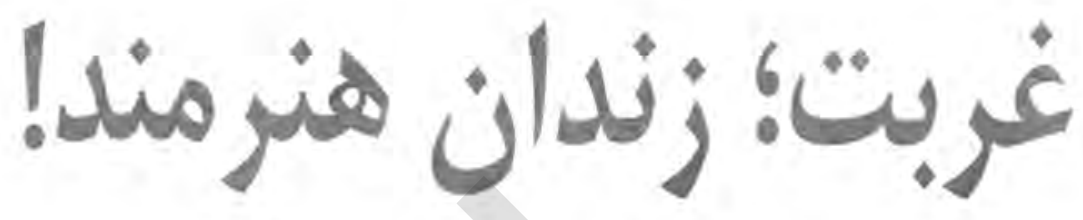
كفتثويى بأمحملامان يوسفي آوازخوان ونوازنده

م لطفاً خودتان را براى خوانتدكان

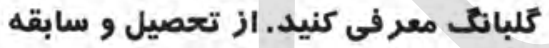
كار هنرى كان بأنوييد.

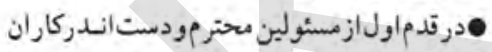

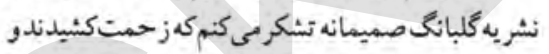

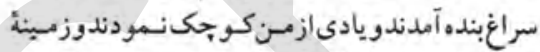

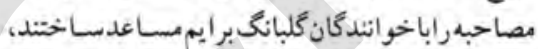

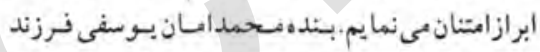

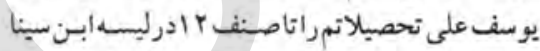

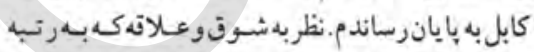

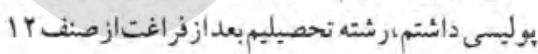

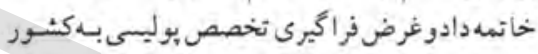

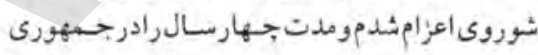

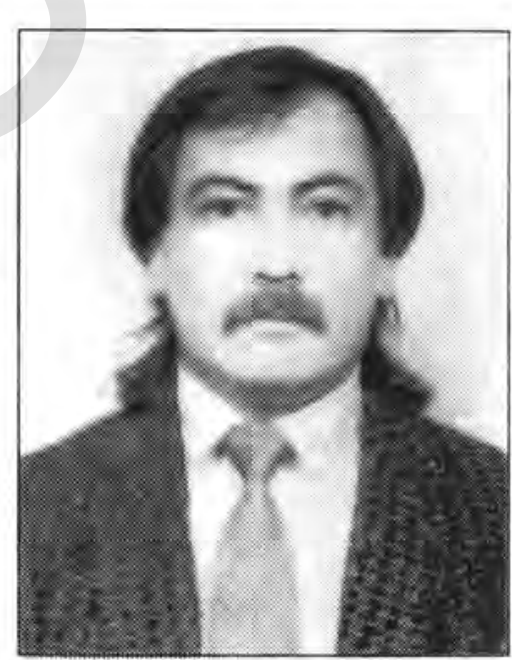

\section{دريا..ي دريا}

آب ابستاده بودونغـاهم مسكرد.اوهـم

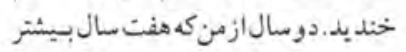

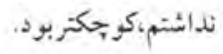

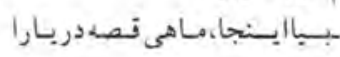

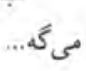

ودوباره سروادر آب فروبردم.

مساهى ازمــن بـرسيد:تـوازكسجا

مى آيى؟

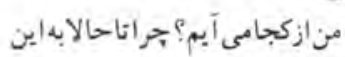

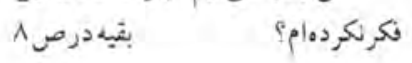

سذيدريزويكدم آراموتـرارنسمىكرنت.

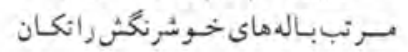

يى دادوبالاوبيايين مى بريد. همانطورى كهدركناركاريز دراز

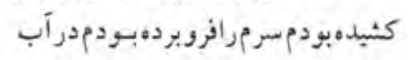

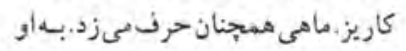

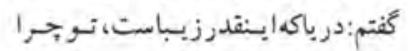

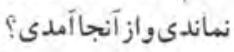

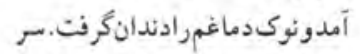
ازأب بيرون أوزدمروخنديدم.درياكسنار
خريا....دريا،عجب جايى اس.سن

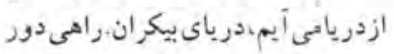
ودرازراييمودم تارسيدمبـهن رودخـانه.

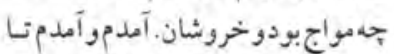

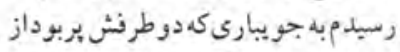

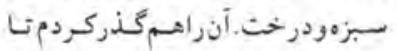
رسيدمبهايشجا.. ايزر أماهى كو جكى مسكىت كهدر

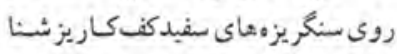

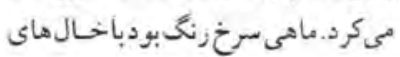

اين شمار هبا آلارىازة: محمدامان يوسفى، محمد آصف سلطان زاده، مصطفى حسام، نعيمى گلكوهى، حميد محصل، قنبر على تابش، محمدانور جاويد، عماد و لطيف ناظمى 


\section{غريت؛ زندان هنرمند!}

\section{كفتتَويى با محمدامان يوسفى آواز خوان ونوازنده}

ايسن جإِونه مـىتوانـن بـه وظايف ملى ذود عمل كنفد؟ • اين جاى شنى نسيست كـ

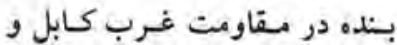
باميان و ساير مناطق هزاره نشـبن

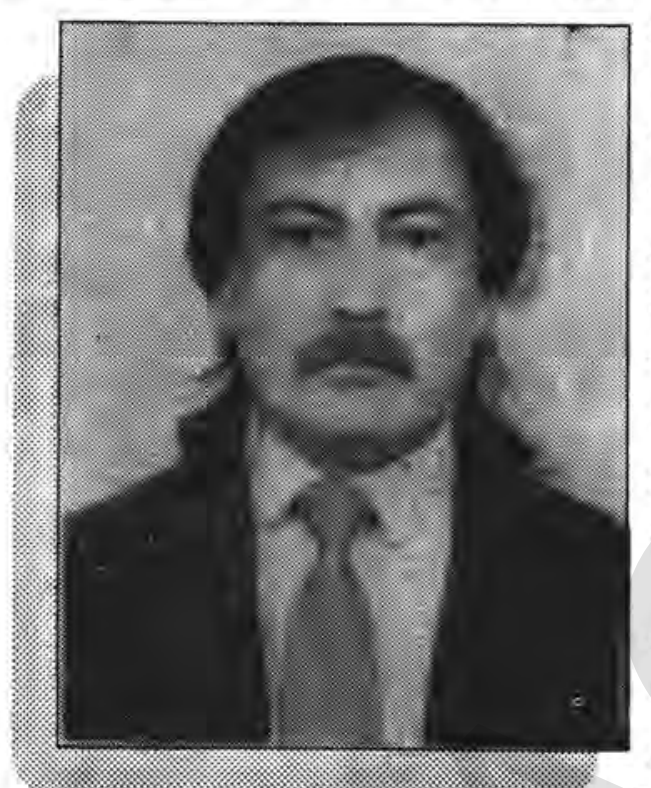
هـمغام بـوده و سهم كَرفتهام و توانستم در ايسن عـرصه رسـالت تاريخى ملى و هنرى خود را انجام دادم و دوشتسادوش سنيخرنشينان حزب و مردم خود عمل كردم و به خواندن اشسعار رزمسى، انسفلابى،

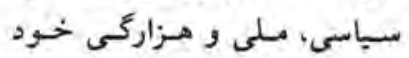
سربازان سنكرنشينان و مردم خود

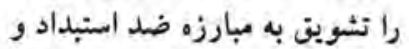

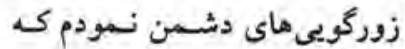
البته نه تنها بنده در اين راه مقدس سهم كرفتهام، بلكه ديخر هنرمندان مليت هزاره نيز به نوبه خود در اين

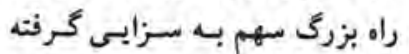

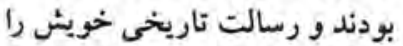
انجام دادهاند. البته هدف فن از آن عده هنرمندانى است كـه رمسالت تاريخى خود را در مقابل جامعه و مردم رنسجديده خسود دركى كرده
دمبور ه را ييشر فته تر نمود. يعنى تـغييراتـى در سيستم

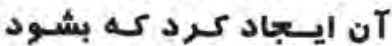
قابليت بيشتر ى ييدا كند؟ هـ از اينكه دمبوره داراي دو

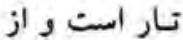
دو تار سـاخته شده نسمى شود كى يكى نار بــ آن اضضافه كرد و با يبك ثار از آن آن

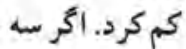

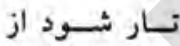
دمبوره خـارج

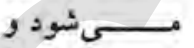

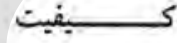
دمبورگى خسو

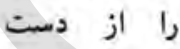

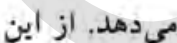

دمبوره آشنايع كامل نداشتم و ائر سمىداشتستم هـم بـا يكى دمبوره

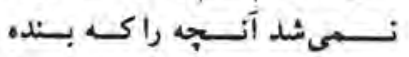

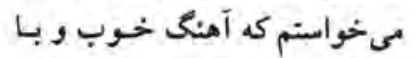

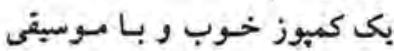

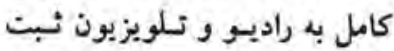
بكنم كه اين رقم با دمبوره انسجام نمىشد و دمبوره به تنهايى خـود

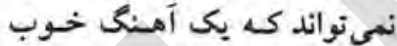
توليد كند و بسعدأ كس بـا دمبوره

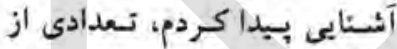

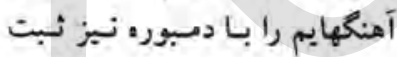
راديو و تلويزيون كردم. ولى آنجه راكه مقامات و مسئولين راديس و

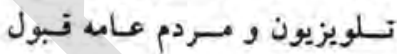

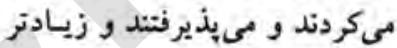

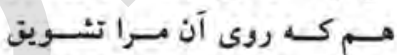
مىكردند اين بودك بايد آهنكهايم روكي

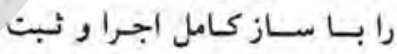

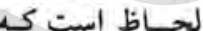
امكان ندارد تغييراتـى در سبــتم

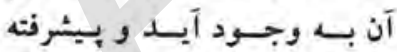

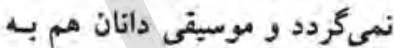
اين عقيده هستند كه جون دمبوره

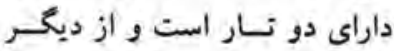
آلات موسبفى دوثر كمي است در ارد صورت مسى الشود دمبـوره تـابليت اجراي آهنگ ييدا كند كى با ديخـر ســازهاي مـوسيفى در نـواخــن ميكس شود و بس.

م شـما از هـنـرمندانى هستيد كه همعام با مقاومت غرب كابل و باميان در ايـن مقاومت سهم كر فتهايد. بـه نظر شما هـنر مندان در آن دوره جقدر توانستهاند بـه تئه تعهد خود عمل كنفد و بعد از تورة تلويزيون كنم كه البته تعداد جندى از آهنغهايم كه بـالاى مـاز اجسرا شده بود خيلىما آن وقت مشهور شل مده بود.

دمبوره هم تـابليت احسـاس بود

هنرمند را دارد و بيان مىكند ولى فيلى

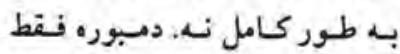
جابگاه خاص خود رادر موسبقى دارد و جون داراى دو تسار است، از لحاظ موسيفى نمىنواند بـراى هنرمند آواز خوان ثرياسر (يسنى:

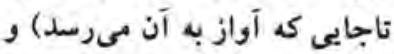

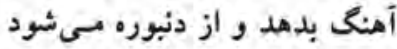
كه در محافل كوجيك در خانه و در

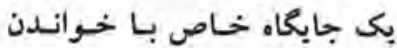
دوبيتى از آن استفاده كرد و زيـاد قابليت ندارد.

م به نظر شـما نـمى شود
بقيه از صرا آناى صفدر توكلى، قدير كريبى وهـمايون لعهلى نسيز در راديسو و

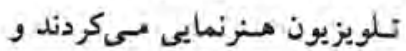

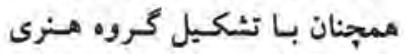
عستقل از مليت عزاره ما توانستيم

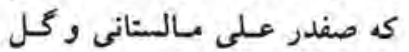
جمن مالستانى را نيز بـه راديسو و تلويزيون بكثـانيم و آوازشـان را ثبت رأديو و تلويزيون كـرديم كــ اين دو نفر با هم دوتايع وبـه يكى تلوين

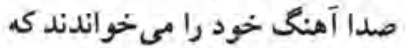
قبل از ظاهر شدن جهره ابشان به تلويزيون آنان به نام آبى ميرزا و وآيا

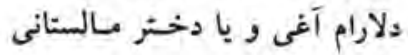
مشهور بودند و مسردم مـا خـوبتر معلومات دارند كه در سال بهال

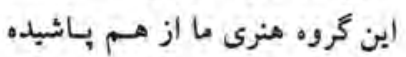
شد وهر كه هر جايى براكنده شد.

م شما بيشتر با سـازهاى جديد مثل هارمونيه و ارك و طـبل و غـيره اسـتفاده مىكنيد حرا؟ مثر دمسبور قــابليت بـيان احســاسات هنر مند را ندارد؟

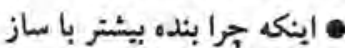

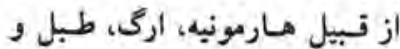

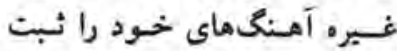
مىكنم و يا آواز مى فوانم عـلتش

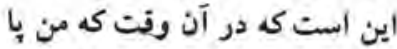

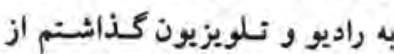

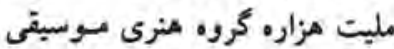
نوأز، كمبوزيتور و آهنگسباز وجود هنري ندائت و من آهنكهايم را از طريت ونيق

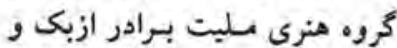

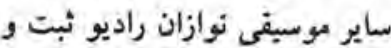
ضبط ميكردم. آن وقت بـنده بـا 
از دست مساند. وتتى يكى مردمه

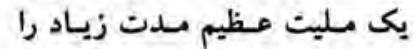
بدون سرنوشت و بدون خط سير و حيران و بريشان در يكى جامعد بدرن

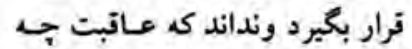

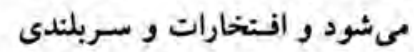

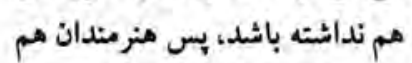
نسى تواند با قلب شيكسته و بدون كـدام تشـويف و دسستخيرى و بـانيا

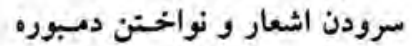
دسبت به كار شوند. حالا شتخصاً خودم بعد از سقوط باميان و ساير نقاط هزاره نشين هيج ائر جـديد

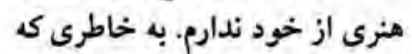
مرنوشت من با سرنوشت مردمر ما ماريا

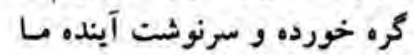

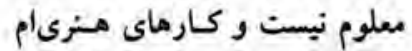

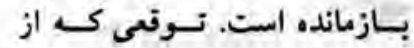

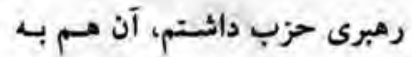
ناميدى مبدل شد. بس جـه بايد كرد؟ شعر است:

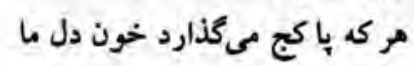

دائم به يأس مبدل كرديد. حسالا

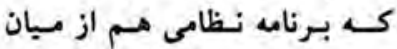
برداشسته شـده و بـايد روى كـار

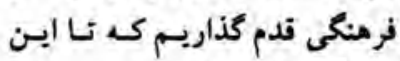
فرهنح عفب مـانده مردم هـزاره

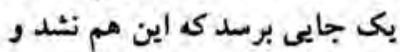

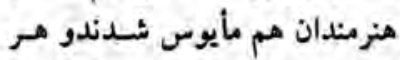
كدام بشتـ كار مزدورى و كاركرى ئري

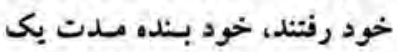
سال است كى بدون مدارك قانونى

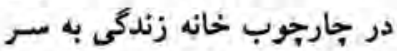

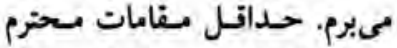

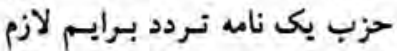

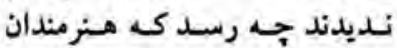
مليت هزاره در يك كـانون مـنرى

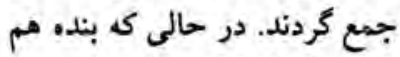

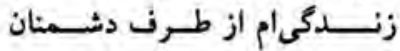

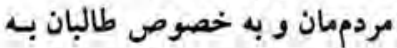

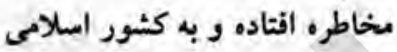

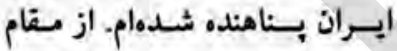
كمك به خود كردم كه تـا حسال

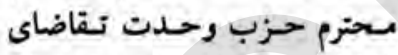

شود و براى منرمندان مليت هزار. كنسرتهاى فرهنكى براي مردم ور ورئر در بين مردم راه انـدازي شـود. از بردي

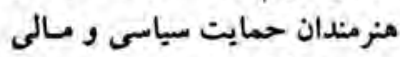
صورت بكيرد و هنرمندان نزديك

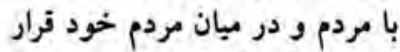

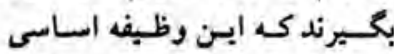
مستولين محترم حزب و و دفناتر حزب در يك جامعه مىباشد.

م بتر نيست هنرمندان هزاره در جهت ايسجاد يك كانون هـنرى اقـدام كنيند و وارئ

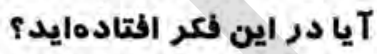
• اينكه هنرميدان هزاره بـايد در يك كـانون

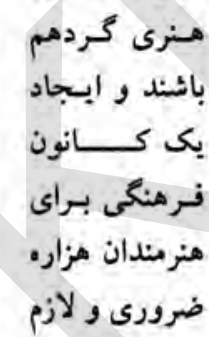

جاى شك نيست كه بنده در مقاومت غرب كابل و باميان و ساير مناطق هزاره نشين همكام بوده و سهم كر فتهام و توانستم در اين عرصه رسالت تاريخى ملى و هنرى خود را انجام دادم و دوششادوش سنكر نشينان حزب و مردم خود عمل كردم
بودند و بـا مساومتهماى مردم و حزب خود سهيم بـودند، نـ آن

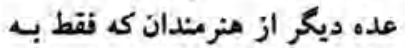
خاطر بيدا كردن يول و به خواندن

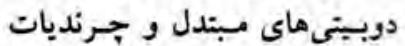

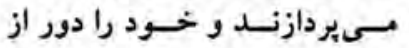

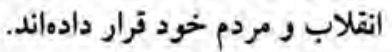

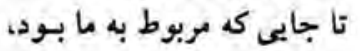
در شرايط خاص به نعهدات و در برد

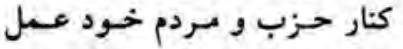
نموديم. بعد از اين هم هـرمبر مندان مليت هزاره مي توانستد بـ هـمان

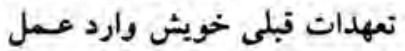

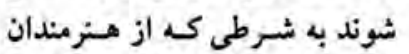
حراست به عمل آيد. از هنرمندان از منرمنان

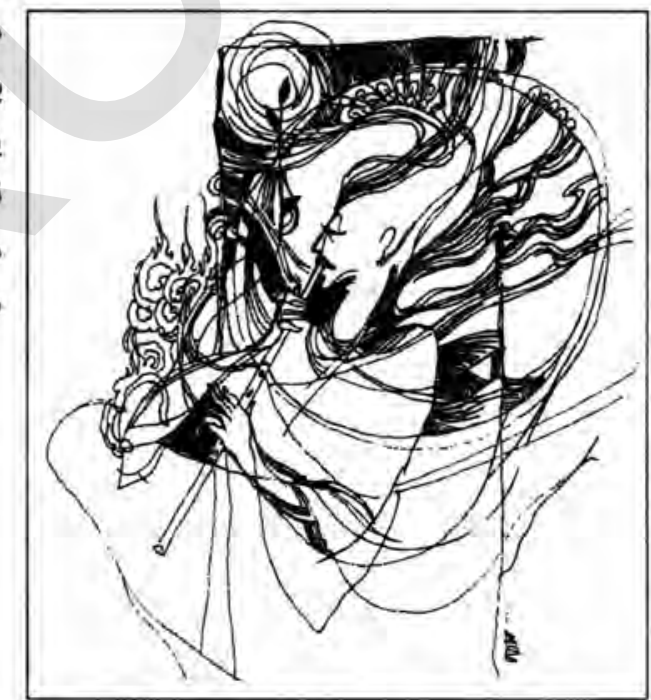

مدت بك سال است كه هيج نوع مىخوريم شيشه ناموس ملت دور بغل داريمما

م حقدر از دوبيتى مايى كـه مسىخانيد از خودتان

است؟

• از الشعار و دوبيتىهايى كه

تا حال جه در راديـو و تسلويزيون انغانستان و جه در ديكر محافل و ورو كنسرتها استفاده و خواندهام تقريباً

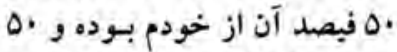

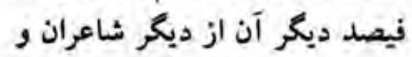
از بعضى كتابهاي الشعار استفاده

كريدمام.

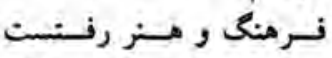
آن طشت زرين بشكستست ورت كـمك از طــرف ايشـان بـرايسم صـورت نخــرفته است و بـدون سرنوشت مىباشم. همان تسم كه سفوط بـاميان،

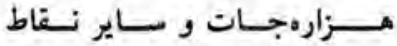
هزارهنشين تأثيرش را بالاى مردم ما كذائت و احساسات مردم ما را

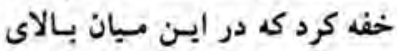
روحيه ما هنرمندان نيز تأنير كرده

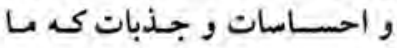

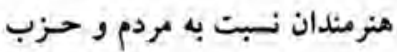
خود داشتيم، اين الحساسات مات مات رات

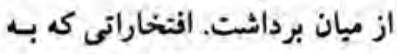

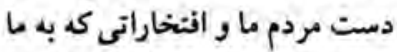
هنر مندان بود آن هم از بين رفت و
است، بـلمى. بــنده در ايسن فكـر

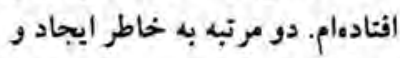
تشكيل بك گروه منرى از مـليت

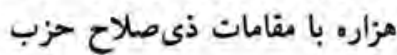

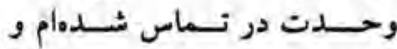
ملاقاتهايى با مسئولين دفتر حزب درب نيز صورت گكرفته است و مكسرر روى ايسن تأكسيد كـردهام كـ أز هنرمندان مليت مـزاره يك گگروه هنرى ايجاد شود و كارهاى هنرى منري را بايد خويتر و بهتر درست بكنيم

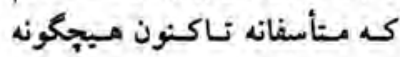

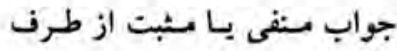

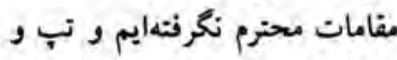
تلاش واميدوارىمايع كه از مقام محترم حزب و مسئولين دفاتر آن
حمايت سباسى، اجتماعى و مالى صورت بعيرد تا اينيكه هـنرمندان اجني

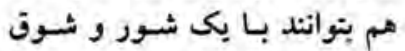
انقلابي دركنار حزب و مردم خود بإبستند.

O به نظر شما هنر مندان هراره حإّونه مىتواتـند در بيان احسـاسات و وضعيت مردم خود سبهم بغيرند؟ • بـ نظر من هنرمندان هـزاره

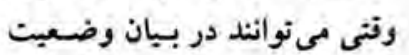

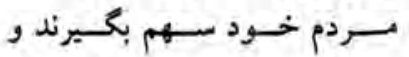

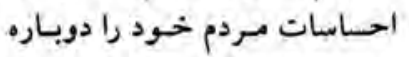
تازه كنتد كه براى هنر مندان مليت هزأره زمينه كارهاى هنرى مساعد هره 
به درياجهما بكويم كه به همه جا

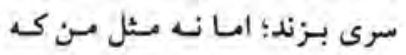

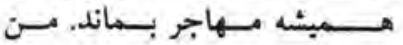
سلىخوامسـم جـون درياجههاى آشفته با تمام اهالى ترانهُ غم انكيز بهار بخوانم و مزٔده دهم كد سفرة:

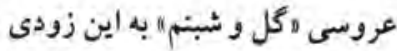
بر جمن سبز و مخملى خانهمامان

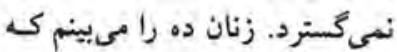

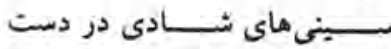
كــرنتهانـد و بـايكويان در دامسن رنغارنكشان آواز و... ميريزند. دختران تبسم با نـاز و كـرشمه در ورد

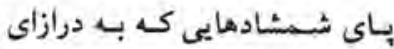
انداعشان رستهاند، اشعار عاشفانه

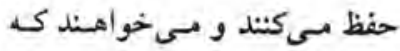
شكوفها رأ با نبسم مهر كره بزنئن

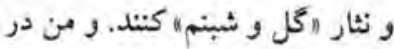
خويش فرو افتادهام شيهية شيبون؛

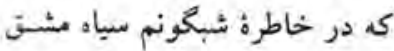
ثبـده است را بـا آواز و هـلهليلة دختران مى آميزم و بادهاي كريزان

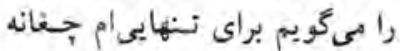

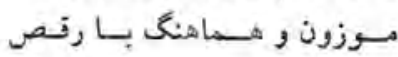
بلكىهاى حريرى دختركان ماهباره

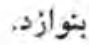
اي بابا! بشئهايم بـه سـويت

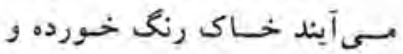

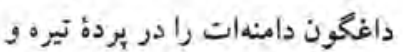
تارش مىسيارد و بعد از عبور، ابر بر بردي

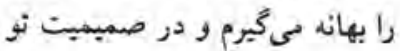
جارى مىشوم نا لالههاى كبود با صيا

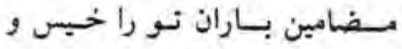
انباشت از ميوههاى بالغ و تازه كند و شكوفه نبسم ـكه خيابانهاى اليان ترك خورده شهر و دزارع سبز بدن بيوكان و نكاه مهتابى دختر كانى كه بهن

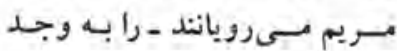
مى آورد.

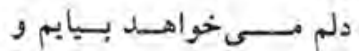
بحويمت كه:كى يبئسانى رنغينت

\section{كالرى}

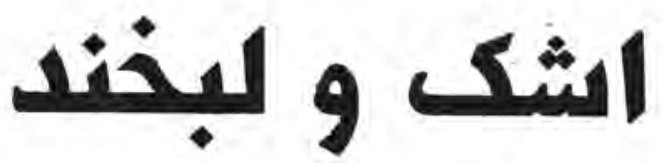

\section{• مصطفى حبام}

دلم مسىخواهـدكـ بينى جكونه در خيابانها نحقير ترا مويه مىكنم! كاش مى ميدى كه من هـر

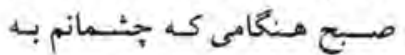
جئشمان خورشيد مى افتبن، اولين كلامم با معامله آفاز مي شود، در بازار اسارت بىروم و برايت غل و زينجير مىخرم! كاش ميديدي كه گـامهايم را بيش از اينكه به مقصد ـ أنجاكى هـجر مرا بختومه مس انعارد برسم، مى مزدند. كَيسوانسم رابـ بازار حراج بى برند. دستان سياه و بي برم مرابه آغوش ميكثيد تامرا به بازى هوس خواهانه بكيرد.

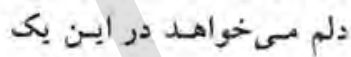
روز باقيمانده از عمرم، ثراتههاى زخهم خسورده و محلى وطنم را

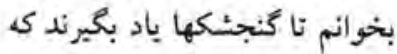

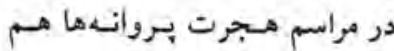

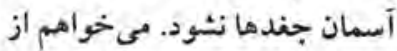
اين جهار ديوارى رنج، نكـاهم را به تو ببخشم و سستارهها در من

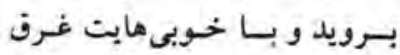
شادى و با فراقت غرق ماتم شوم! از بس كه فضاى إبـنجا آكــندة از تنهابي و بىكسى است. مىخواهم گكريه شومي تسمام

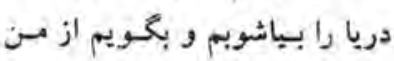

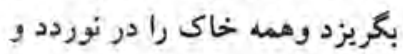

ظلمانى، در اين خسنحى و نحقير. مى خواهم به نحورشيد بحُّيم ديكر بار ترانسهاى فـم انخّيز در غروب غربت من ننوازد و نتهنهاى

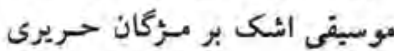

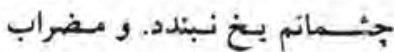

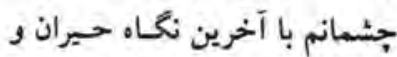
نكرانش در ترديد و غم با شككو. درهم نريزد.

ميخواهم اشكى شوم تا تمام ويسرانسىات را شستـتشو دهـــ و

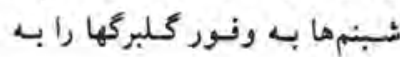
أغوش بكثند و لبها بـ مسحض

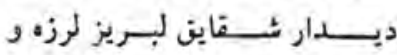
سرشارى از بوسن شود.

صلد حيف كه اين سان شـد

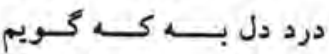
حستجرهام بسياه بـوئيده. جشـــهايم در تـلاقى بـا دبـدكان تبدارت بيوسث زخمهاى تسنت را مورو ميكند.

اي كـوه بـابال آى هـمه جهيز

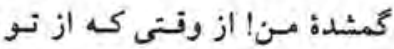
خداحافظى كردمام، تـا هـنوز در راهم، سفرم هـرگز بـايانى نـدارد. جهار باييز كه خاطرات شيرين بـا تو بودن رادر ذهنم زئده مىكرد، ممه كذشت، ولى بابيز كه با تولد

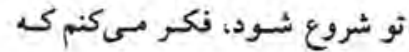

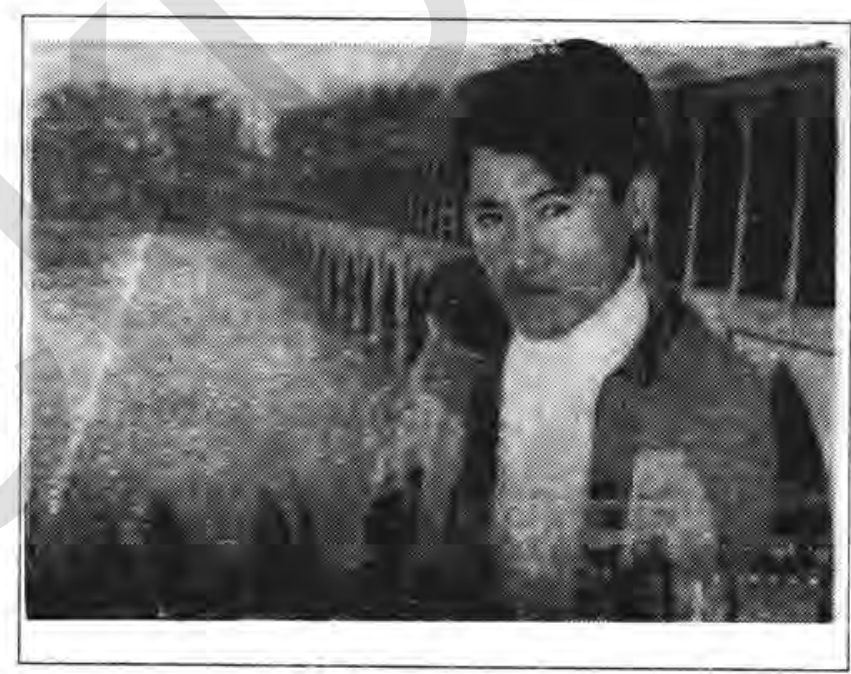

هركزّ به جشم نستواتسم ديـد، زيترا تسمام مرا نبيشتر غربت سيوراخ

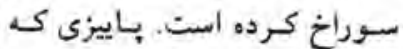
قلبهامان را شكسته و جشـهـامان را يخ بسته. باييزى كه "يرىهاه را با نان و سوكند معاوضه كرده أست. نوجى از سر و تن دريده در

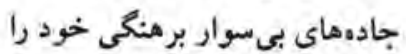
جثن كر فتهاند. كـاش لبـخند مسى شدم نـا صياءترين و برافروختهترين رخ را

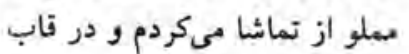

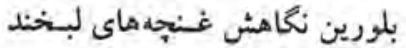

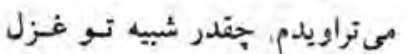

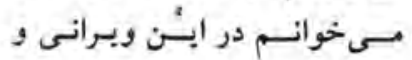


خورشيد قدم بزنند و بـ لهجههاى صميمى و متبرك بروانعها بـاكـل

ابريشم عميقانه كوش دهند.

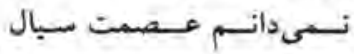

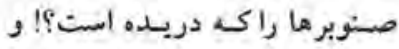
نجابث و بإكى كلدانهايى كه يبامبر كـودكى مسرا رشـد مسئداد كيى

$$
\text { شكستصن }
$$

أَه كابل إ من ديكر با بكى مبد

برنده و سبيده مى آيم و كُلويم را

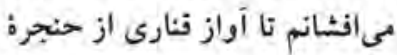

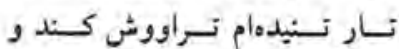
مىخواهم كه به ربستينكاء سبلامم هبجكس لبخند اجابت نريزّد. مسن لهن
بـهيّ از بسيدارى تسبير و تسفسير شدة مام.

و من مىخواهم با برستوما در

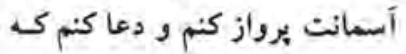
بالهاى جرخبالهایى موشك انداز از آه مردمم بسوزدا من مي خوخواهم

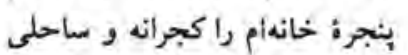

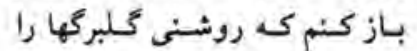

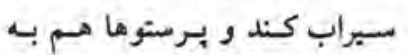

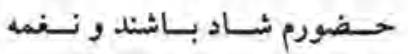
بخوأند و به من اجازه دهند زخم جهار بسال تنهايقى و غربت رانشر دمب من ديخر زو به خداي نبايش
هم اكتون در زمستان خودم بسر مسىبرم. نسيبم بسهارى از سن دو كرفته و انسبوهى از بـايزم. روزى بـ جــند كـالبدم را در صــندوقجه ربسواى خـوامـند كـذاشت ور در

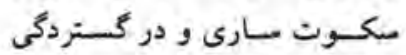
خاكى ميان آتش و خاكستر علتهبم

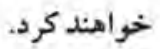
اي بأبال أخرين ديدأر من و تو روزى بودكه فقط بـا بسايهمانان

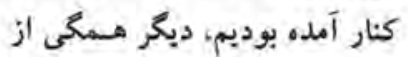
ماكر يخته بـودئد و بـا دستهاى مسمومعان بر نشانه هامان زديم وربا اشماره با هم خـــاحسافظى كـرديم

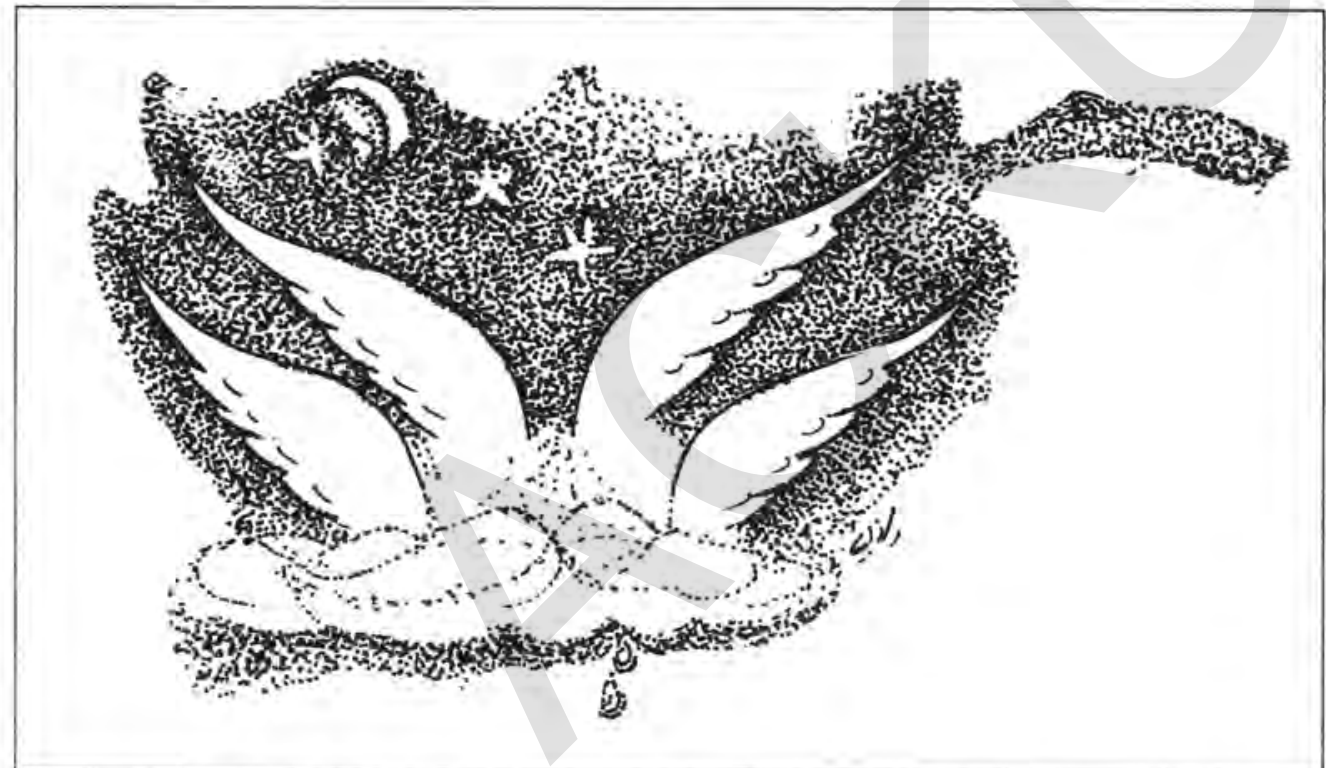

و آنتابخردان دوتـايع بــ نـوازش كلها مي رويم و با تكلممان هيجخاه

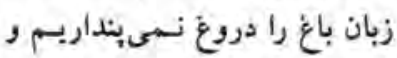

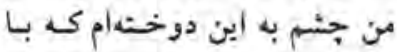

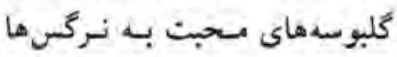
احترام كذاشته شود.

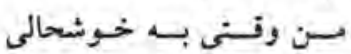
مىرسم كه بهار، ثيكوفن را هديهام كند. من قلبم را در سر دروازة نشهر

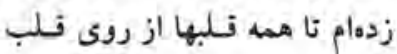
محزونم تقويمهاشان را تنظبم كنتد و بـ صلع و زندگى ايمان بياورند.
مىكثم كى از تبازم مستنفر نسباشد و هميشه در كالرى الشكى و لبنخند حضورم مرى آويز نداثته بأشم. من مى خواهم كه أز شانعهاي شب به جكاد سيبده بـرسم وبـا شهوت، شراب شسفت بسنوشم واز

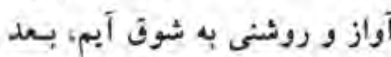

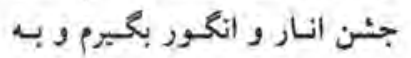

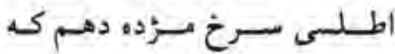
عـروسىات نتزديك است و مسن مست از اينكه جشم مرا بحنوشيند. من ديخر خسته شدهام! مـردم مرام بايد خبروشان در راستاى بهرواز
وجدا شديم: ولى اكئون هـرجـ حدس مسىزنم كـ آيـا بـراي بـار

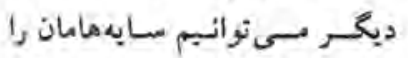

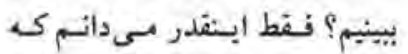
أَسمانت را مه غلبظى بـوشانده و

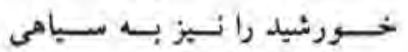

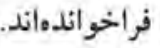

يَئ از أذ من خوابهايم رادور تصنيف بـاران تسبير مسكردم و

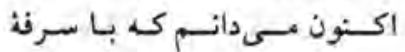
كلاثنينكوف و تير باد و راكت و... كه قلب مظلوم دختركان و بسران دهكدةام را نشاند ميكيرد خـودم
را شستشو مىدهى؟! آيا مىدانى

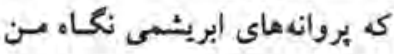

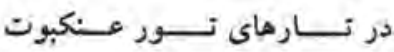
خاكسترى وكينه توز و بي عاطفه بـ

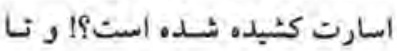
كى مىخواهى كه جشمانت روى

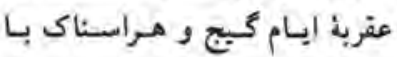
مرئيه ما ور بروند؟؟ اي بابا! قلبم متروىترين محله برون

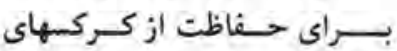
لاشخورى شده است كه نمى توان ناهت را با كودكىترين مرد دنبا بـر لـرد زبان آويخت. و اكتون شحبوس و بىنام و نشان در سايهماي انـدوه راه مـىورم. دخــتران هـم ديخـر مريم و شبنم نمىكارند. سكها به جاى كبوترها نـامهماي عـاشقانه مى برند و مسى آورند. مسن ديكـر عـوض شـدهام. وفتسى كـ زيسر

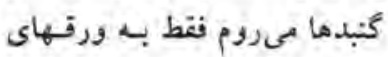
نارنجى وطلايى جشّم مىدوزم و دأنهاي يافوت ولاجوردي ونى سين

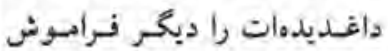

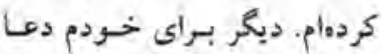
نمىخوانم، دست نياز بـ نسوى نرون

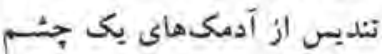
خورشيد في فرده، ديـدكانم دراز نىكنم. نسور رادر جشسيهاي أدم نسماهل جستجو مسكند و نسور ستئاره را نراموش كروه است. من ديخر آواز

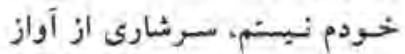
جكاوكم. در محبوسيتزين تنظكناى

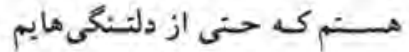
خسته شدهام. من ديكر خـونم در ركهاى كبوتر جارى نيست. و قلبم نيز كمثلده و يا در سينة آدمكهاي جادوكر و اغوا كنتده مسئبد. مسن ديكربه بكارت درختان سيروركه تزديك بنجرهام روييدهاند، ايسمان

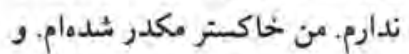




$$
\text { رقص بركار }
$$

• محمدائور جاويد

سر شكاز ديدهبر دامان من هموار مىرقصبد شكوهى آسمان بر خفتهة تبدار مى قصيد زمان بر ساية يك شاخه مىلغزيد، مى إلطيد جواشك از آسمان عالم دوار مىرقصيد شرف دركوجههائسردغربتخاكبارانشد ودستى با عروسك بر سر بازار مىرقصيد سياهى سايه افكنده است در بيج شبستانها دلى در لايههاي سينهُ تبدار مىرقصيد دلى در محبس فريادها گم مىشود، اما صداى صاف كاغذ بر دل بركار مىرقصيد (اصفهان)

إ

• حميد محصل (توين)

بى تو يك شب رفتم و شيدا شدم ذوق بودم يك بغل نجوا شدم با بلور اشك شعرى ساختم فطره يودم موجى از دريا شدم در ميان دردهاى بىشمار جلوهاى راديدم و بيدا شدم در سراى حرفهاى بى صدا شوق بودم غنجهه بودم وا شدم كى شود او در دلش جايم دهد اصفهان $\log 5$

ت نعيمى كلكوهى

جه دستى مىزند قلم براى طرحكونهات؟ همان طلوع رنك غم، غروب بىنشانهات

مكركه كلكآسمانبهنقش بستهاينجنين؟ "(به ريسمان زخعها سكوت ساليانهات") به هر كجاكشادهاى دو بلك نازنين فتط دو جشم سرخ ديدهام ز رنك عاشقانهات اكر جه نيم باورت به خون نشسته خواهرم ولى دوباره سر بده به رنغ گَل ترانهات بخوان به كُش آسمان كه بارورشودزمين و بشنوند ((جغدها)) سرود جاودانهات اصفهان

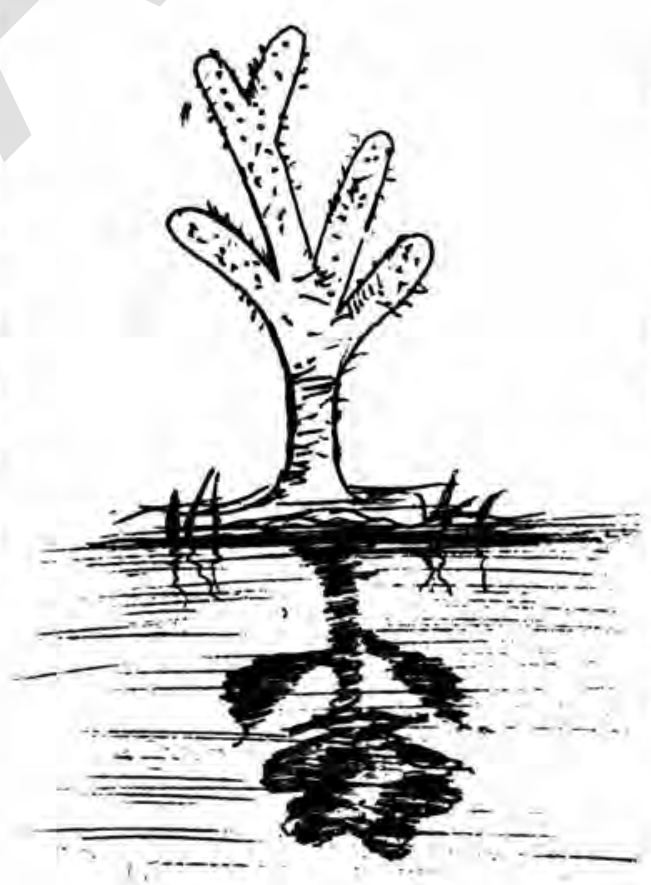

• مabia حسام

$20 \%$ وقتى كه از نكاه تو آغاز مىشوم سرشار از ترنم و آواز مىشوم آنغاه كه بلك ناز تو آونظ مىكنتد من هم به محض اشك تو ابراز مىشوم وقتى كه شروع مىدهى: ييوند مىخوريم مملو ز شوق و وسعت برواز مىشوم كاهى كه ناز مىكنى و بلك مىزنى

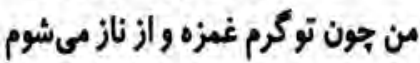
رسواى من مكن و مده شور و ولوله در خلوتكه يكسره همراز مىشوم تكرار مىشوم به تبسم، به غمزههات وقتى كه با طلوع تو آغاز مىشوم اصفهان

ace

$$
\text { ترا مىخواهم امشب در كنار بستر سردم }
$$
ترااى عشق خالص ایى تمناى دل دردم

دو جشم شوخ ومستترابراى(باد))مىخواهم وخود مانند گيسو غنجهات را حلقه مىكردم

مرا با خود بير تا آبشار نيلآكون خويش و مى از جام حشمانت بده يك لحظه ياهردم صداى آتش استاينجاوديخ عشقمىجوشد همان ديكىكهدرآنحس خودراغرقمىكردم

مرابا خود يبر تا انتهاى كوجهاى آرام! ودر خود محوكنمنراوبىخودكندلدردم اصفهان 
آر به خائهُهنرفتَّ... • لليفع نامهى

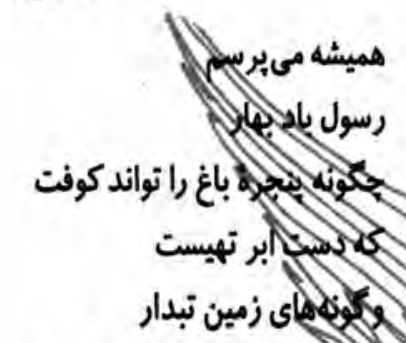

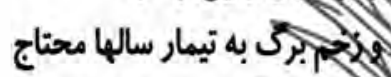

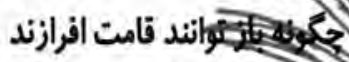
أكر صنوبر وكاج؟

اكر به خانه من رفتى سلام من به درختان سوكوار بكو به جلكَهاى سترون به بركه بهاى تهى براى جنكل بىباران كه خواب سبز شدن رار ربود ربودهاند ز جشمانشان شب تاراج

اكر به خانة من رفتى بكو به جشم براهان بوسههاى سحر جكونه جلجله برگردد؟ كه باغ زندانيست و عشق در تبعيد و شانهاهاى رهايى به زير خنجر خشم ديل وقلب سرخ شكفتن را حصار تنگ هزاران خدنگ را آماج

بياز من سبدى بر ز عطر ياد بير

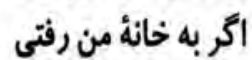
اگر در آن ميقات اكر در آن معراج آن ميمات
دختران جشئم بادلهى: ق قُنبرعلى كايشن

سلام اى دختران جشم بادامى! من امشب شعر جشمان شما را مىسرايم باز

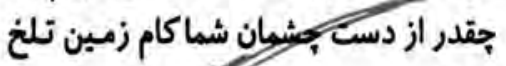

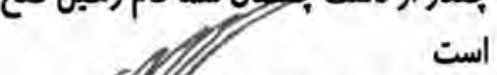
است

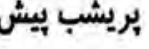
دلش خون بود

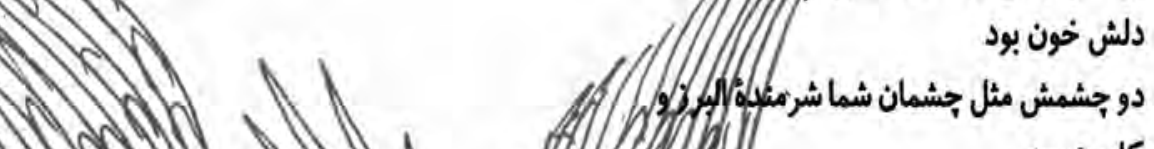
كارون بود بريشب مادرم كابل تمام كيسوانش را به دستش كند ودر مانيل
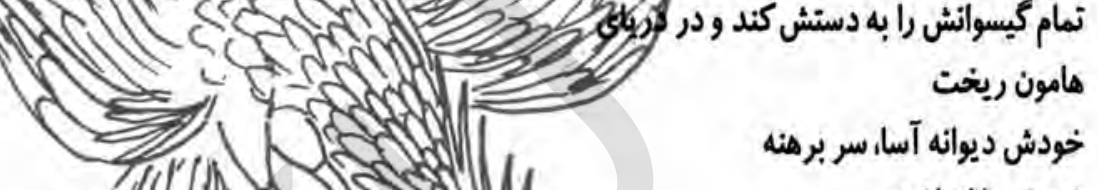
خويش را انداخت ميان موجهاى باغى هلمند

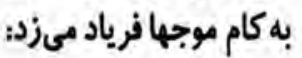
كجا شد دخترانم؟ دخترانى جشم بادامى. سلام اي دختران جشم بادامى هزاران باركه جشمانم به جشمان شمان افتان باخود آرزوكردم

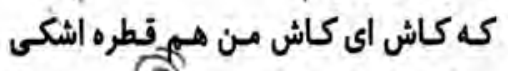
(1) مىشدم يك روز ومىغلتيدم از مزئان خونين شما بر خاك سبى در خواب ديدم مادرم لب يكى جوى بر خون ايستاده مخته مىخواند دو مرغى ناكهان از آسمان آمد و هر دو بالهاى خويش رادر جوى بر خـون

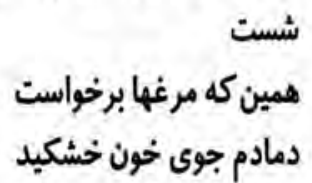
و مادر بر در آورد و به سوى آسمانها رفت جه كس از جمع تان خواب مرا تعبير خواهد 


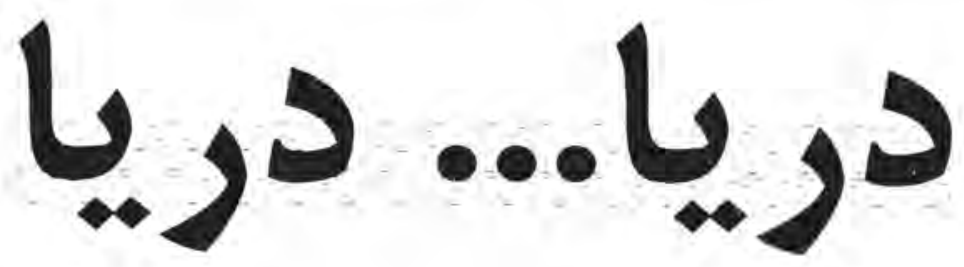

\section{• محمدآصف سلطان زاده}

بدهد. تندوسريع بركشيدود لابلاي سنكريزهها نابذيذ

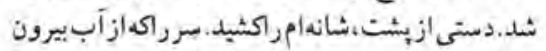

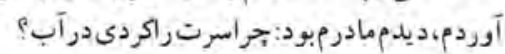

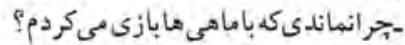

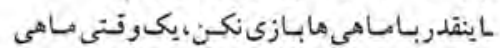

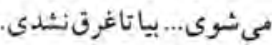

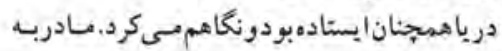

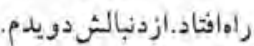
مادرمت ازكجاعى أَبم؟

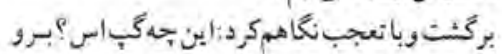

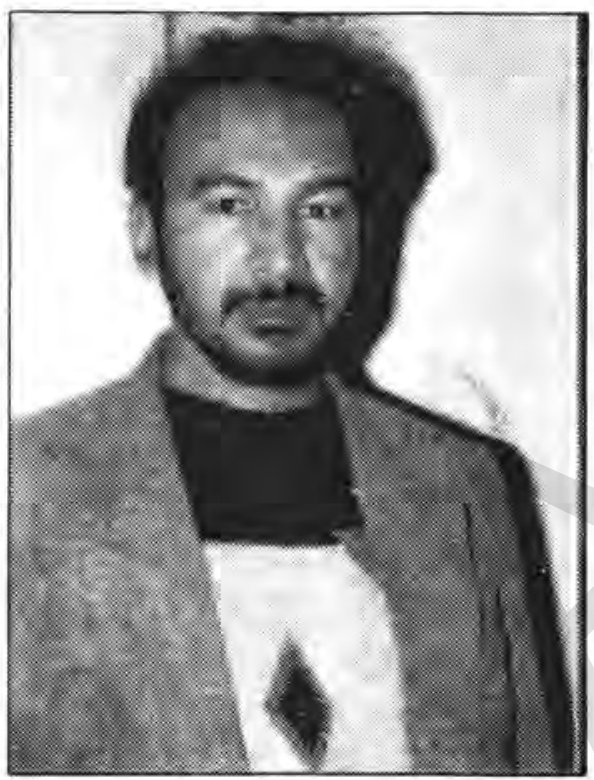

بانجهدهابازيكن

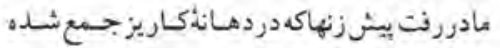

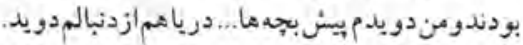

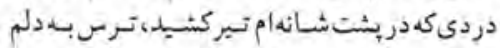

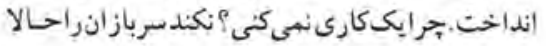

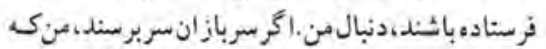

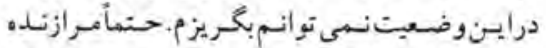

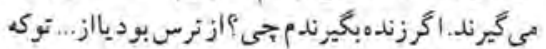

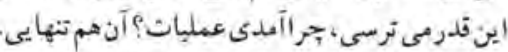

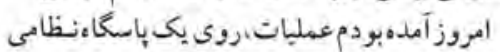

مشترك روسهاودولتيىها.

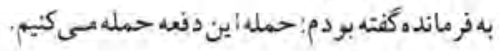

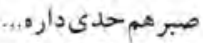

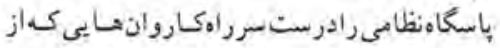

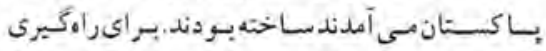

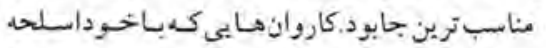

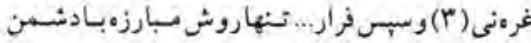

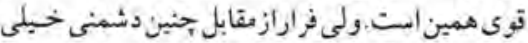

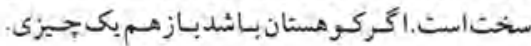

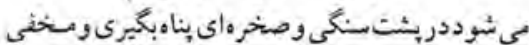

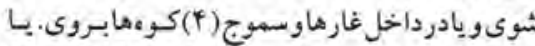

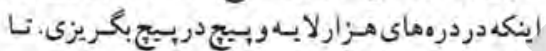

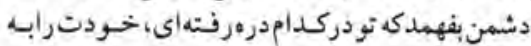

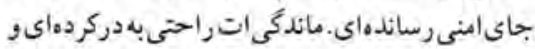

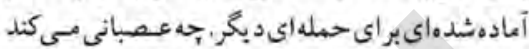

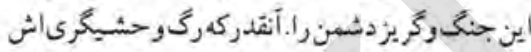

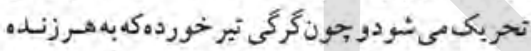

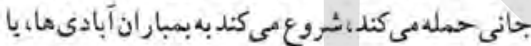

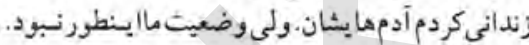

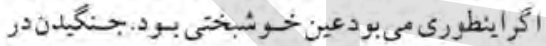

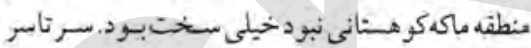

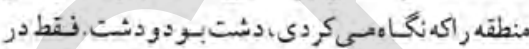

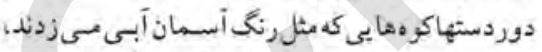

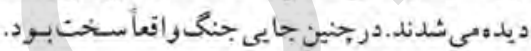

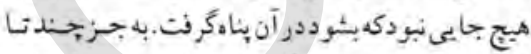

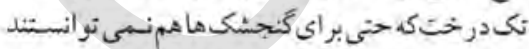

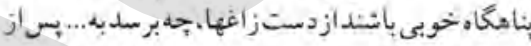

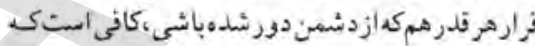

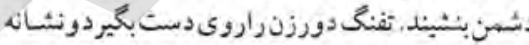

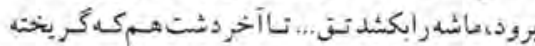

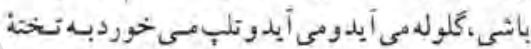

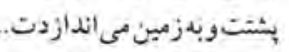

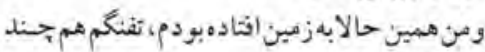

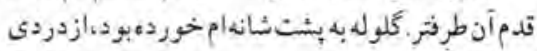

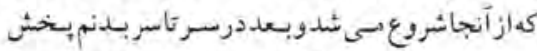

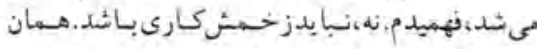

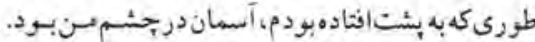

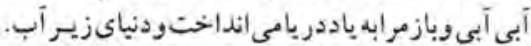

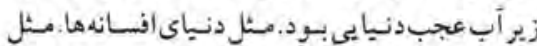

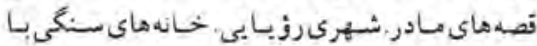

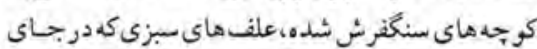

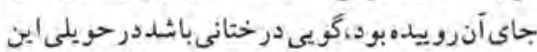

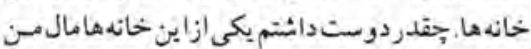

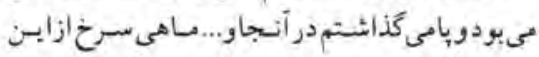

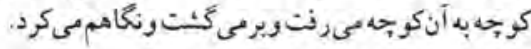

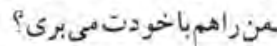

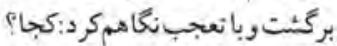

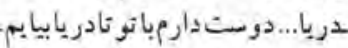

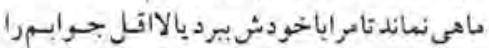

$$
\begin{aligned}
& \text { من....راستش نمى دانم ازكجامى آيم....فكركــماز } \\
& \text { ولث هبين جابودم. } \\
& \text { نه، أين طورنيس . هبكى ازذدريامى آين. } \\
& \text { ازدويا؟نها }
\end{aligned}
$$

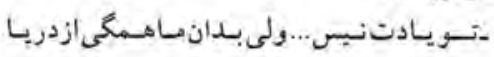

$$
\begin{aligned}
& \text { لرياجطورجايى اس؟ }
\end{aligned}
$$

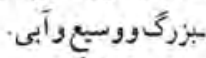

$$
\begin{aligned}
& \text { درست مثل أسمان. }
\end{aligned}
$$

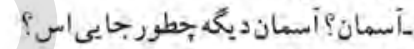

$$
\begin{aligned}
& \text { ماهي باكنجكاوى برسيد. }
\end{aligned}
$$

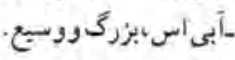

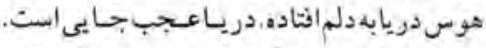

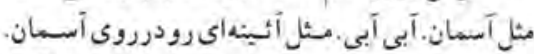

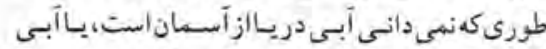

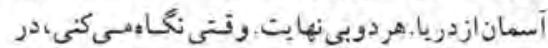

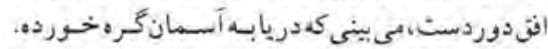

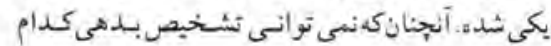

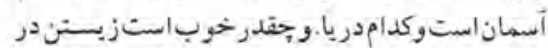

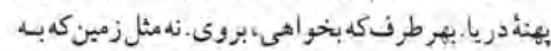

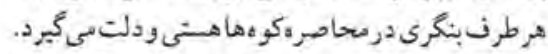

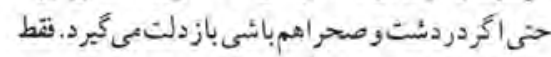

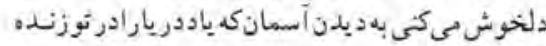

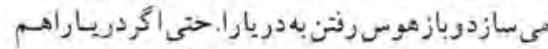

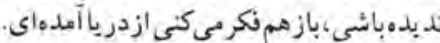

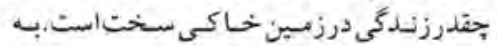

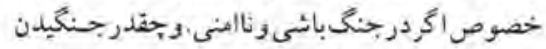

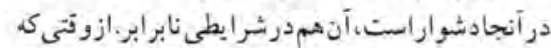

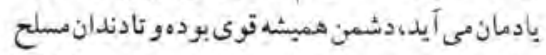

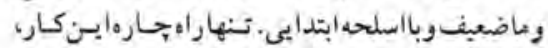

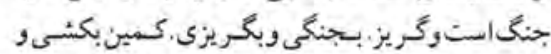

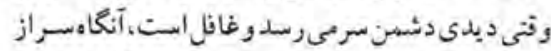

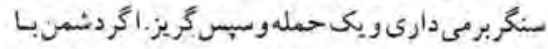

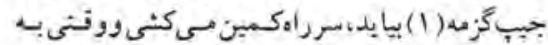

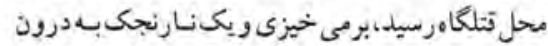

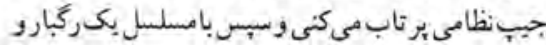

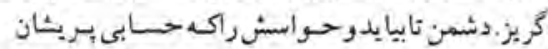

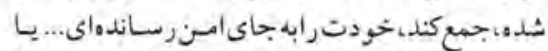

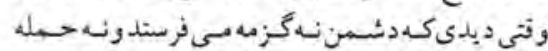

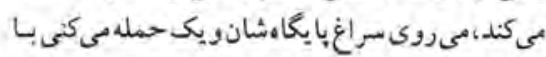

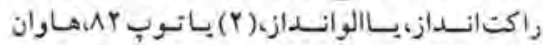


شانها يش جنمى مي اندازم

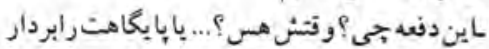

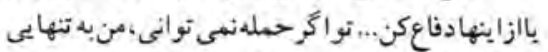
حمله مىكنم.صبر عم حدى ادواره... بايدبرخيز م.نبا يدهمين طور انتاده بمانم. اين ازهـر

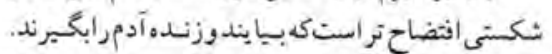

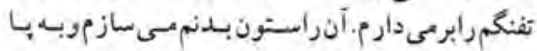

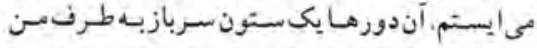

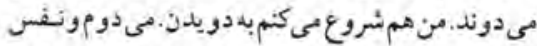

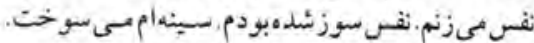

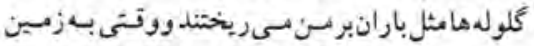

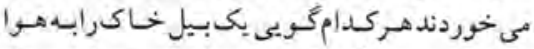

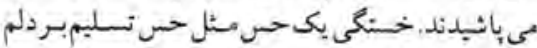

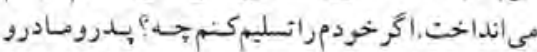

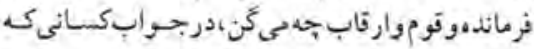

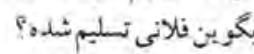

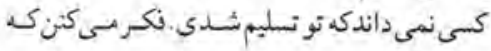

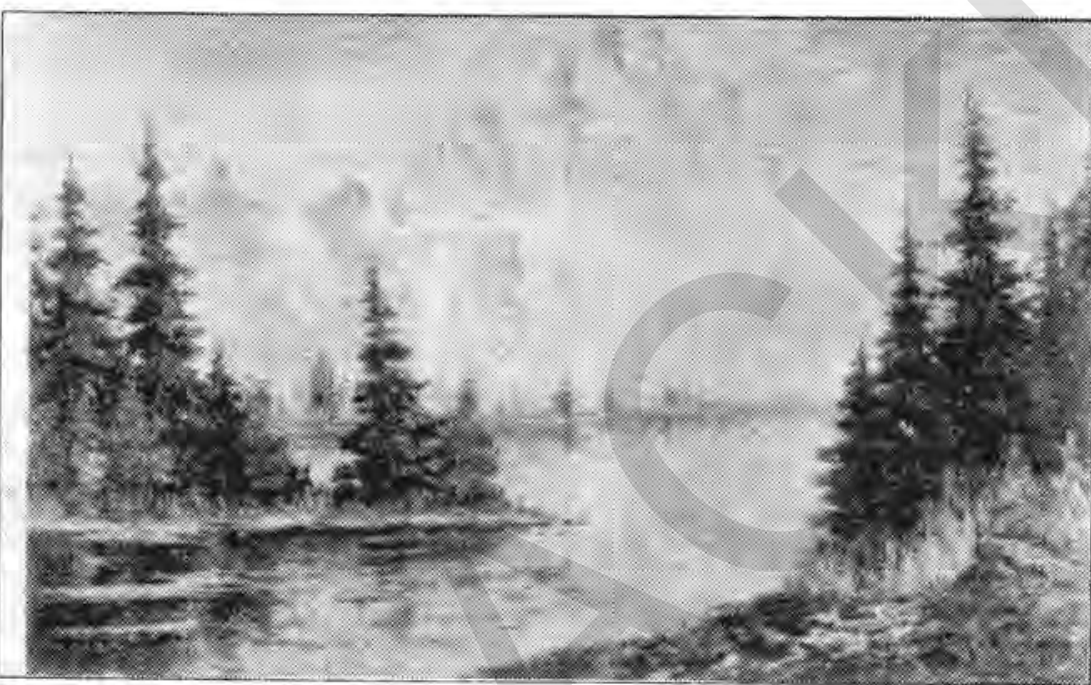

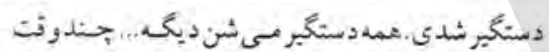

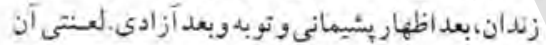

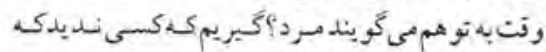

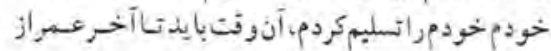

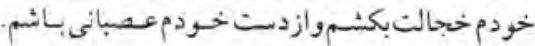

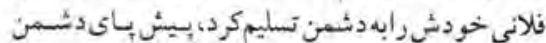

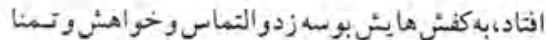

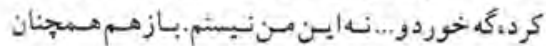

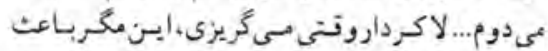

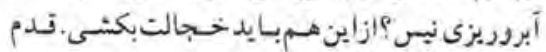

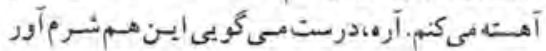

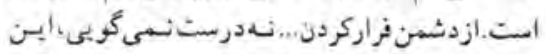

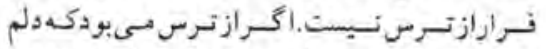

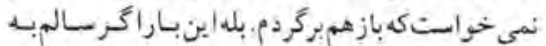

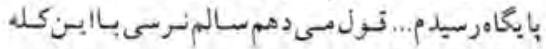

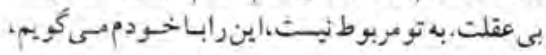

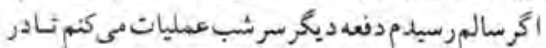

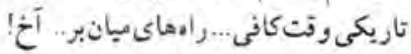

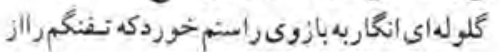

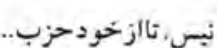

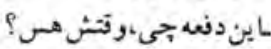

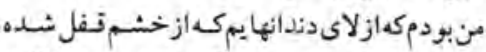

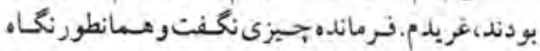

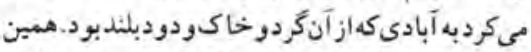

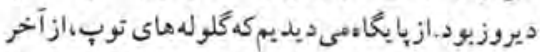

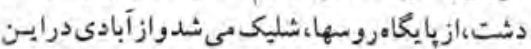

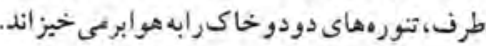

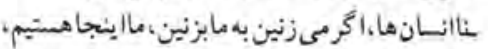

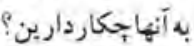

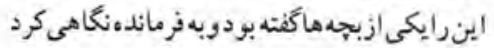

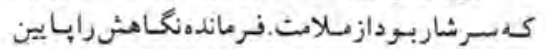

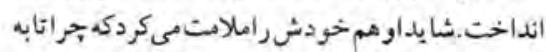

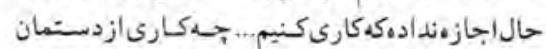

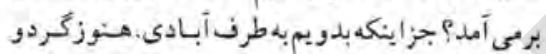

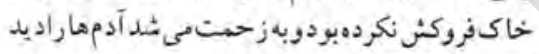

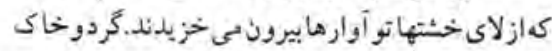

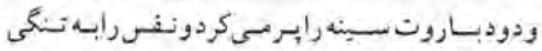

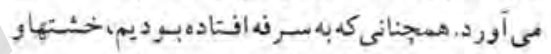

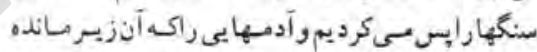

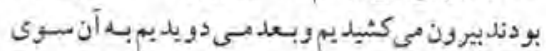

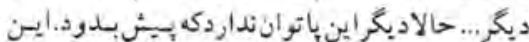

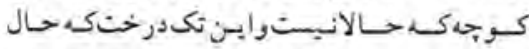

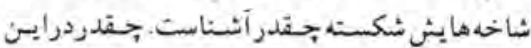

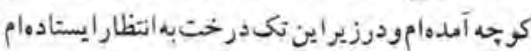

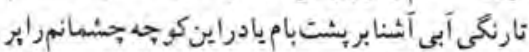

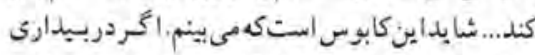

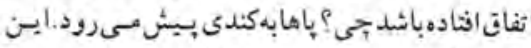

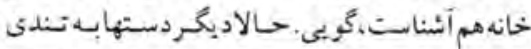

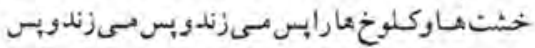

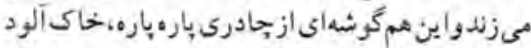

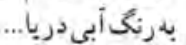

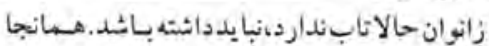

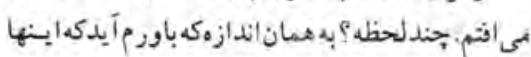

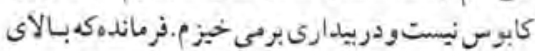

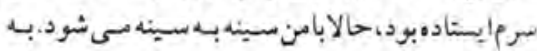

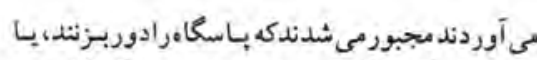

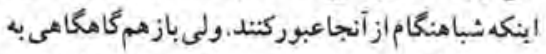

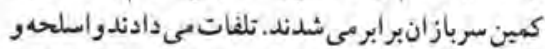

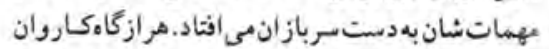

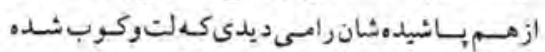

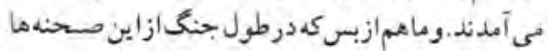

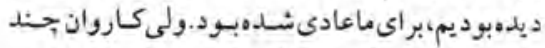

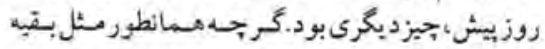

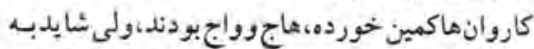

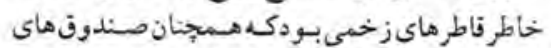

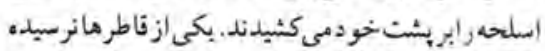

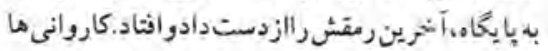

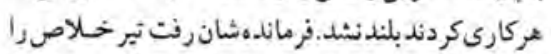

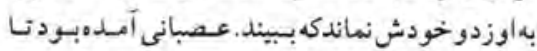

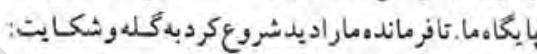

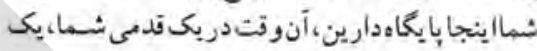

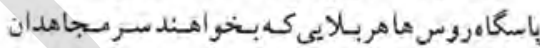

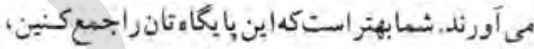
ونتى نمى توانين امنيت راءرابكيرين.

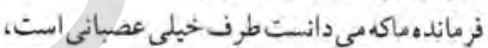

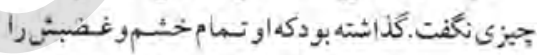

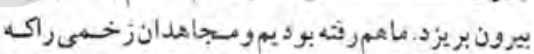

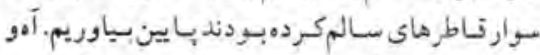

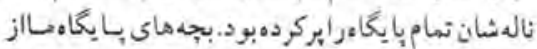

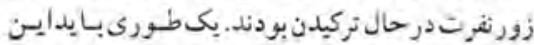

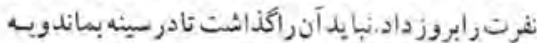

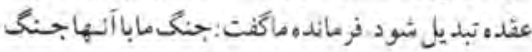

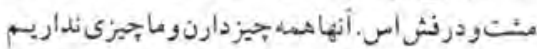

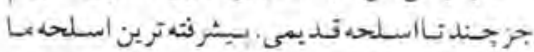
كَلانسينكف أست

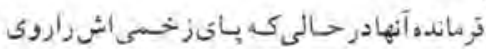

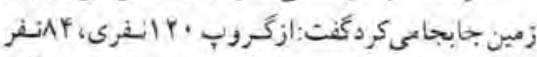

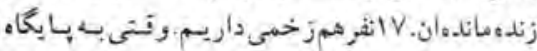

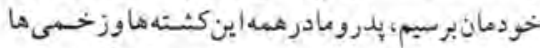

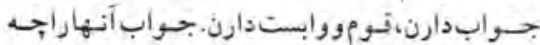

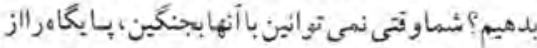

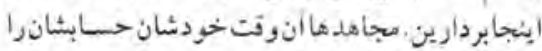

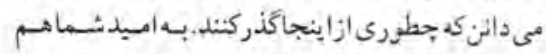

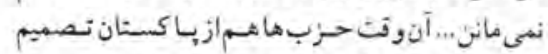

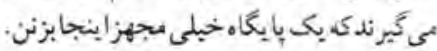

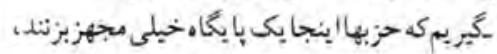

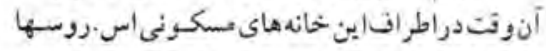

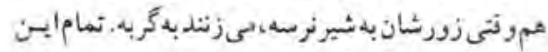

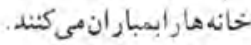

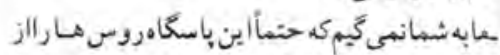

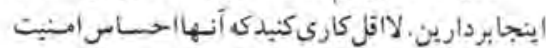

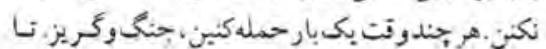

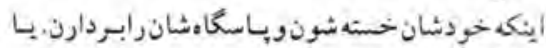

اينكه ازموضع تهاجمى بله موضع دوناعى بناه ببرند.

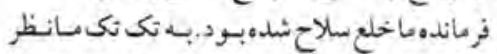

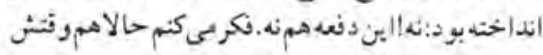




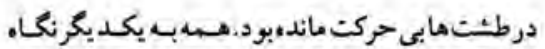

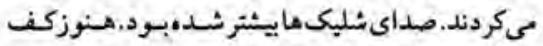

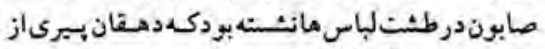

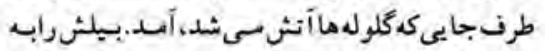

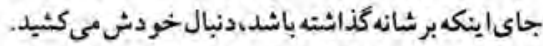
-جهاخبراس،كاكاقتبر؟

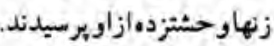

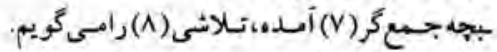

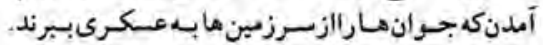

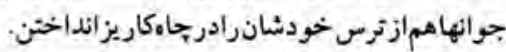
كمى مابودن؟

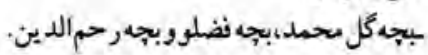

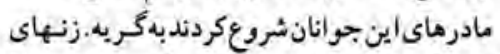

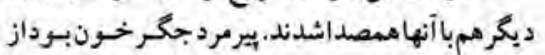

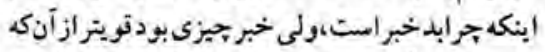

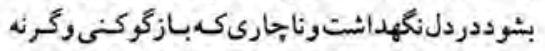

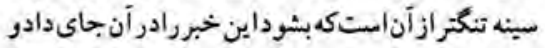

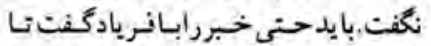

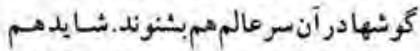
براىاين خبر راشروع كردبه بازئركردنكـ

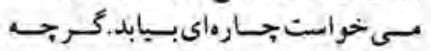

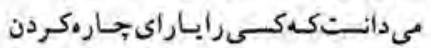

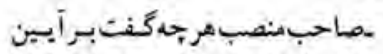

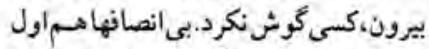

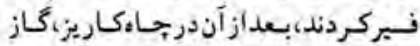

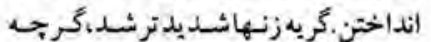

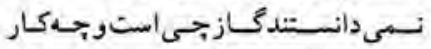

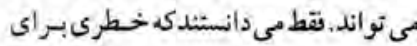

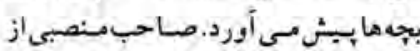
لاىكرت هاي كندم يبداثيدورجهار تأسرباز

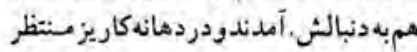

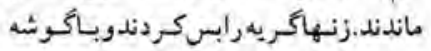

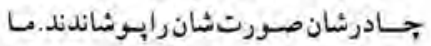

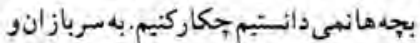

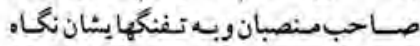
مىكرد يم. صاحب منصب كلاهش رابرداشت وكثفت: مسا

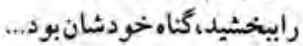

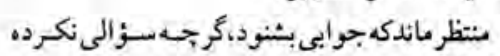

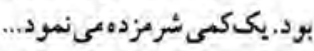

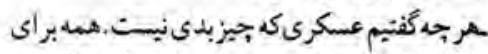

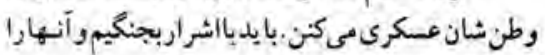
نابودكنيم. زنهاهيج جيزى نكفتند. ثقط كا كافنبركفت أشرارهم

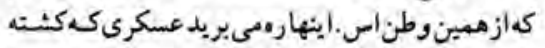

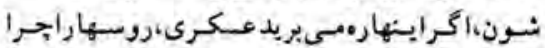
آوردين... - آن

صاحب منصب سكوت كرد.بود....

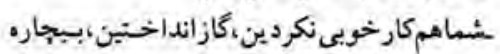
جوانهاران... - ج

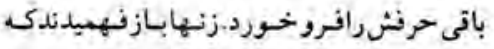

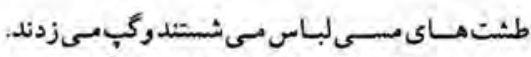

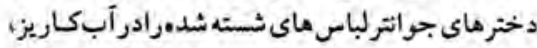

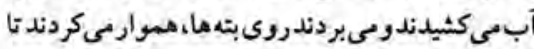

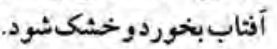

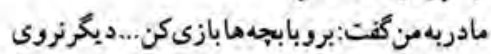

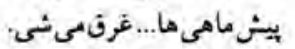
بيابريمبازيكنيم.

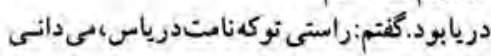
دريايعنى موم!يعنى يك جيزخوب...

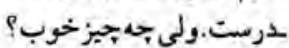
- يعنى يكدختر خوربت

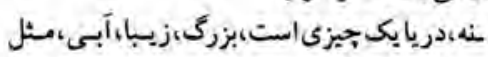
آسنمان. مثل بيراهن من.

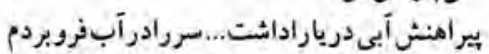

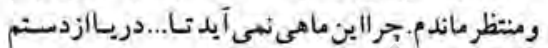

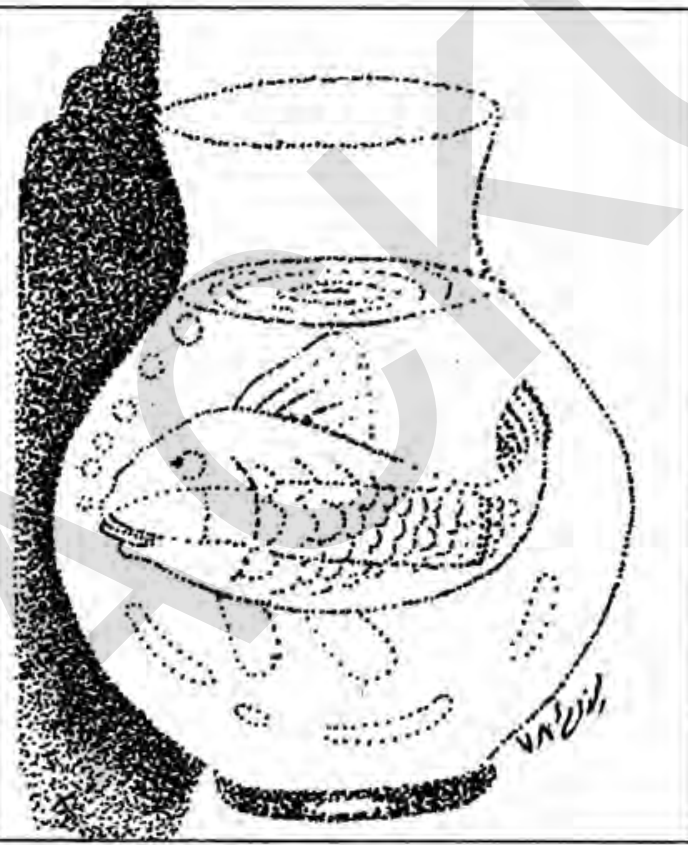

كشيد.سرازآب بيرون آوردم.ازجى ترسيدهايزدرياك

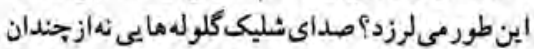

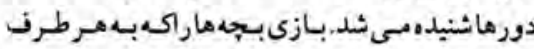

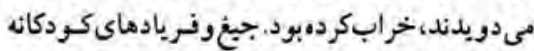

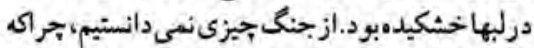

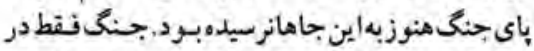

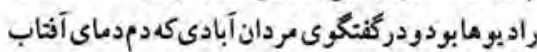

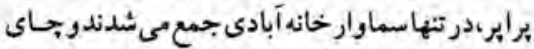

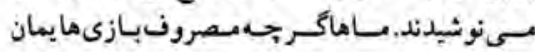

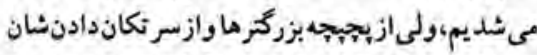

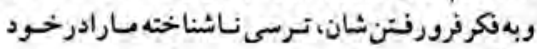

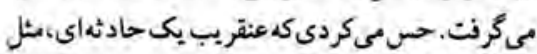

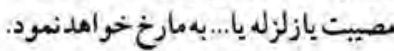

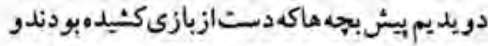

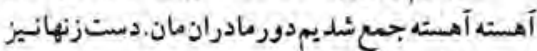

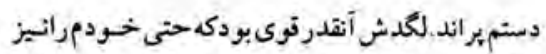

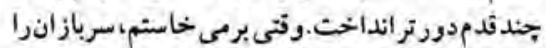

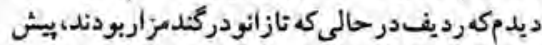

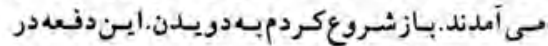

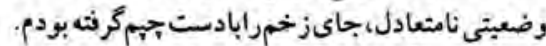

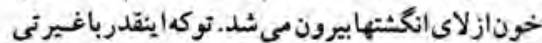

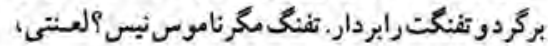

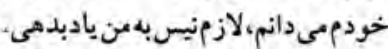

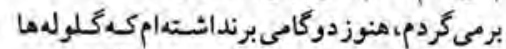

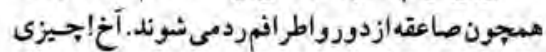

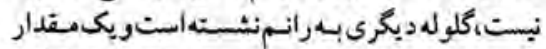

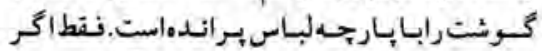

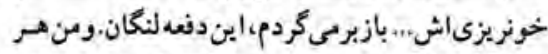

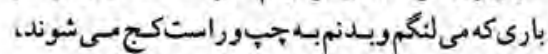

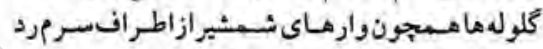

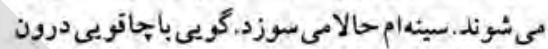

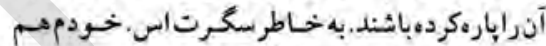

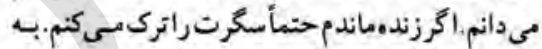

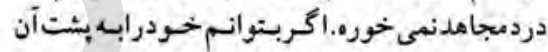

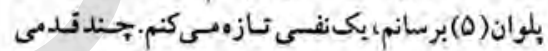

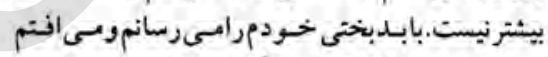

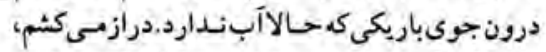

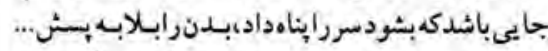

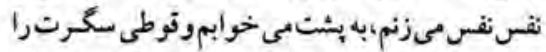

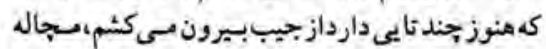

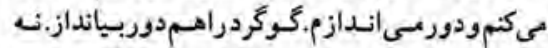

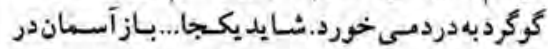

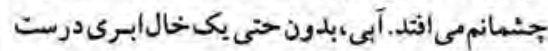

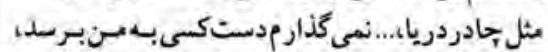

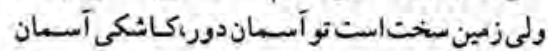

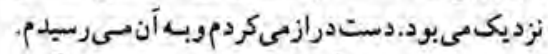

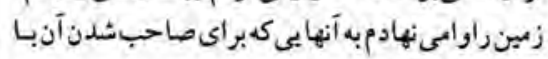
هم ستيز داشتيند.

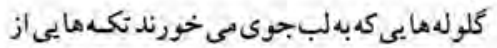

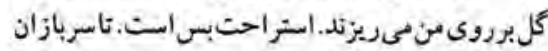

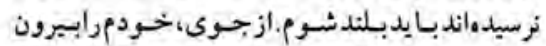

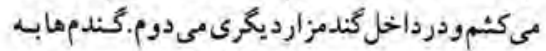

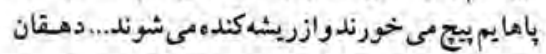

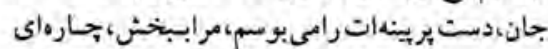

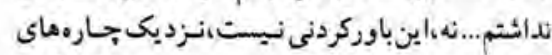

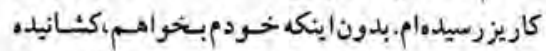

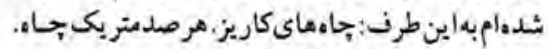

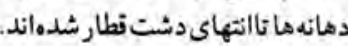

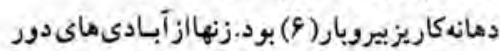

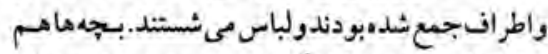

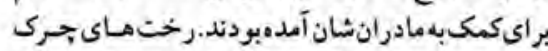

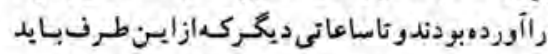

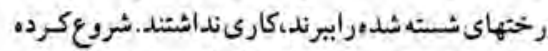

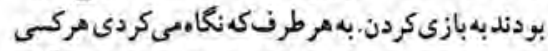

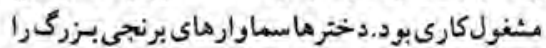

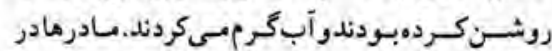




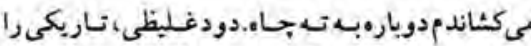

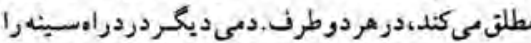

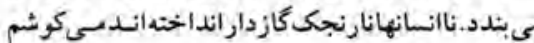

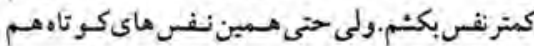

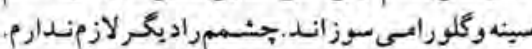

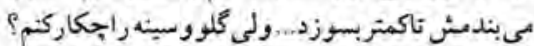

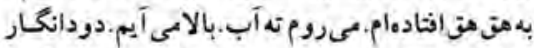

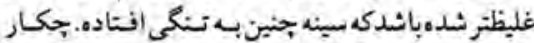

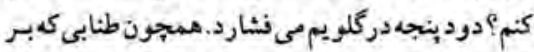

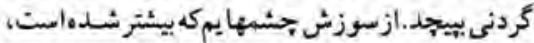

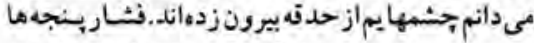

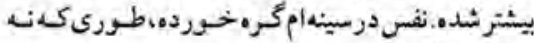

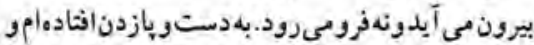

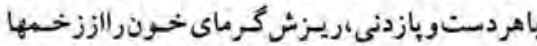

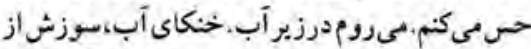

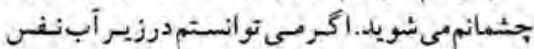

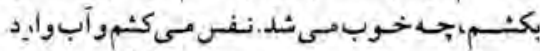

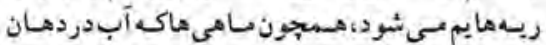

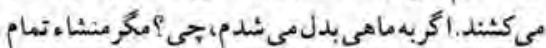

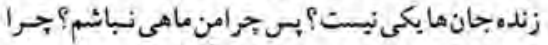

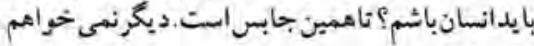

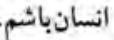

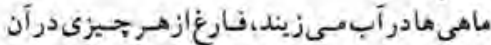

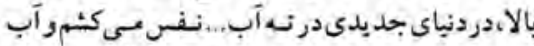

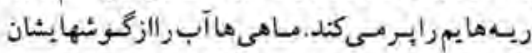

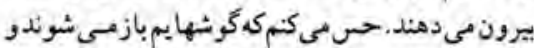

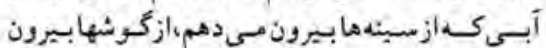

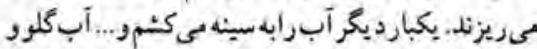
سينهام راكه مي سوخت، آر امش مى بخشئد. حسالاديخـر

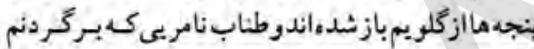

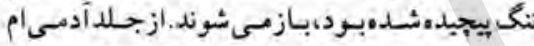

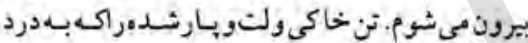

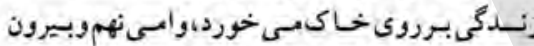

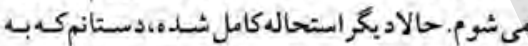

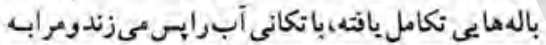

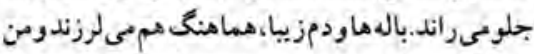

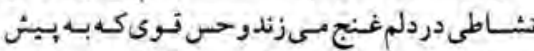

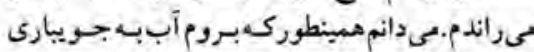

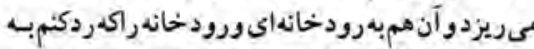

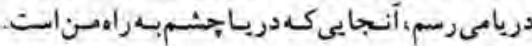

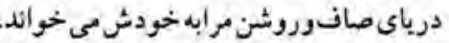

بي نوشتها:

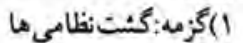

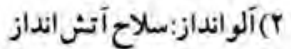

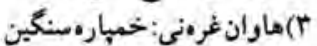

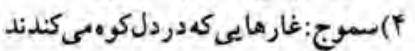

) بلون:مرزبين دومزرعها

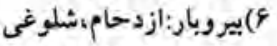

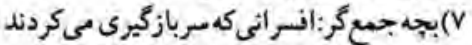
1) تلانتى:سربازي، متر ادفسربازئيرى
اكر....مزاحمثراكمئكتم.

حالاديكر جشمانمب تاريكى عادت كرده.

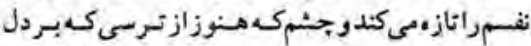

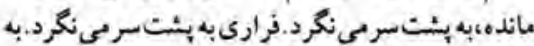

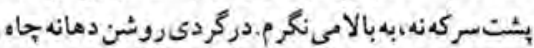

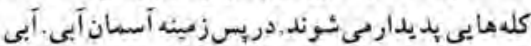

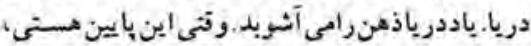

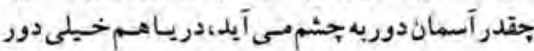

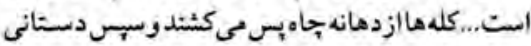

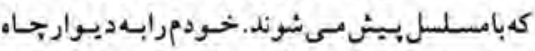

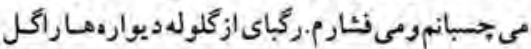

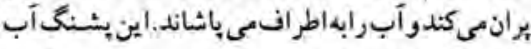

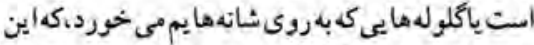

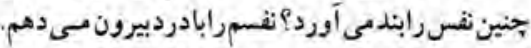

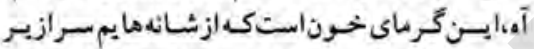

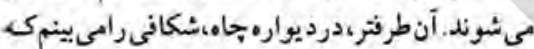

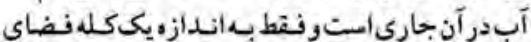

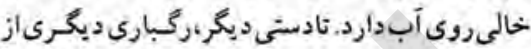

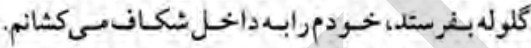

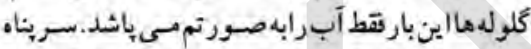

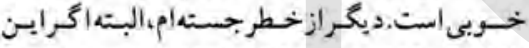

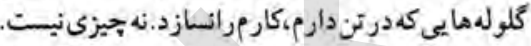

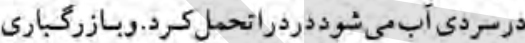

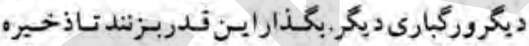

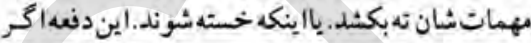

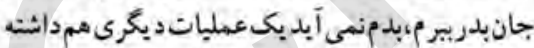

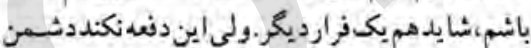

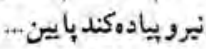
ازئشاف ييس مي خزم.تركيدن نـارنجكي دربشت

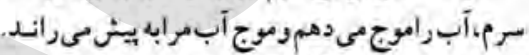

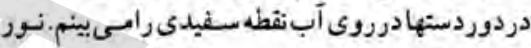

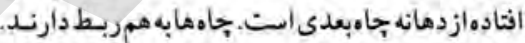

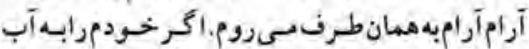

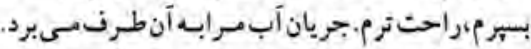

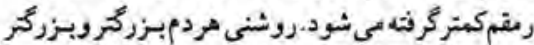

ميشود.

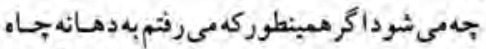

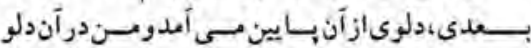

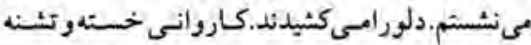

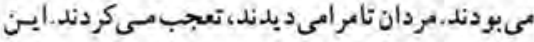

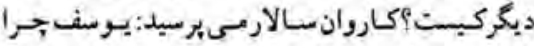

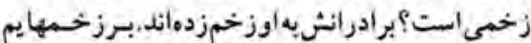

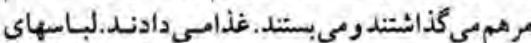

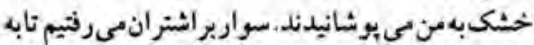

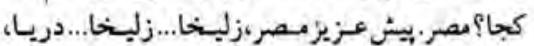

به جاهبعدى رسبدهونر سبدهامكه قلو.سنكى انكار

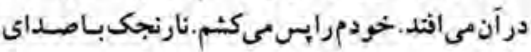

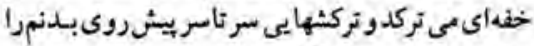

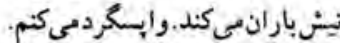

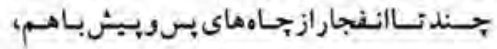

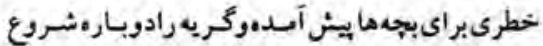

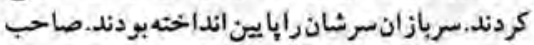

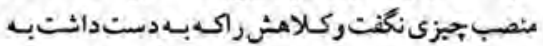

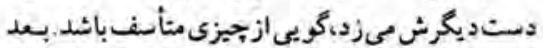

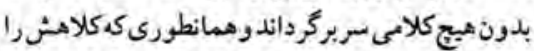

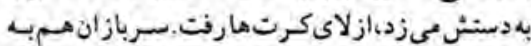

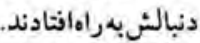

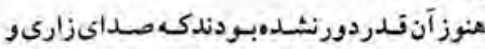

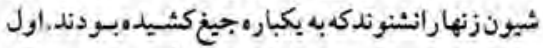

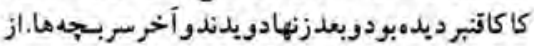

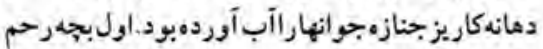

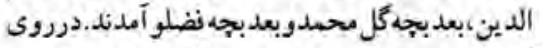

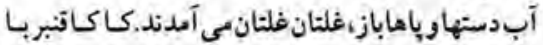

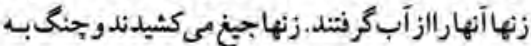

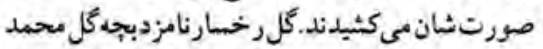

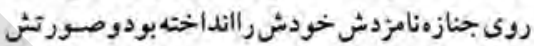

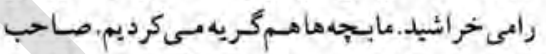

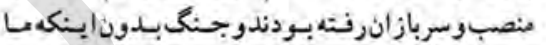

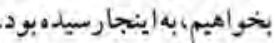

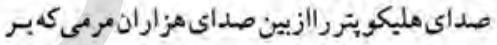

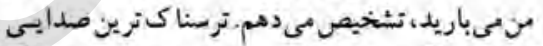

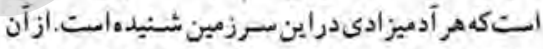

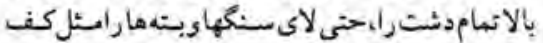

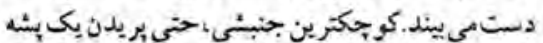

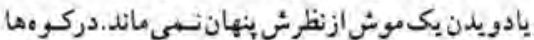

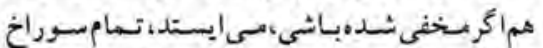

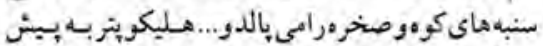

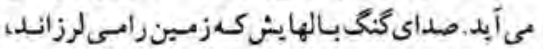

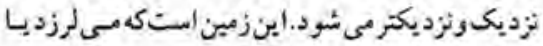

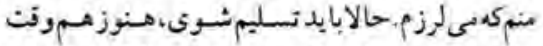

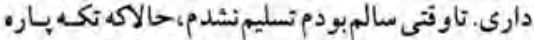

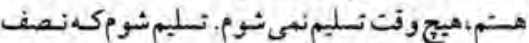
جان خودمر رانجات بدهم؟نصف جانكية بنسرم تسليم

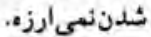

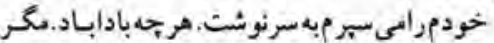

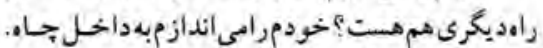

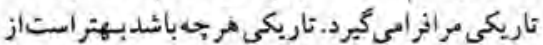

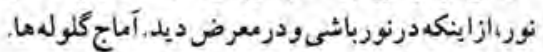

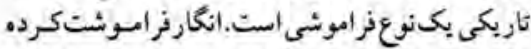

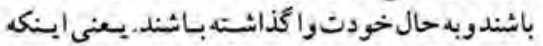

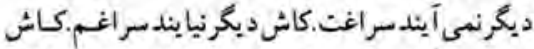

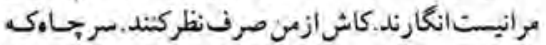

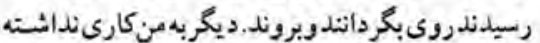

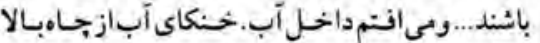

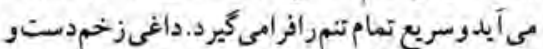

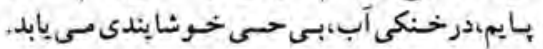

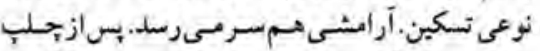

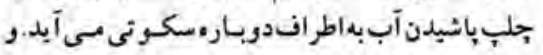

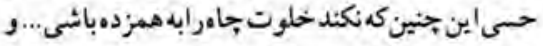

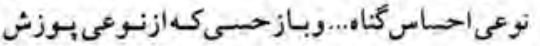

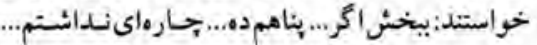




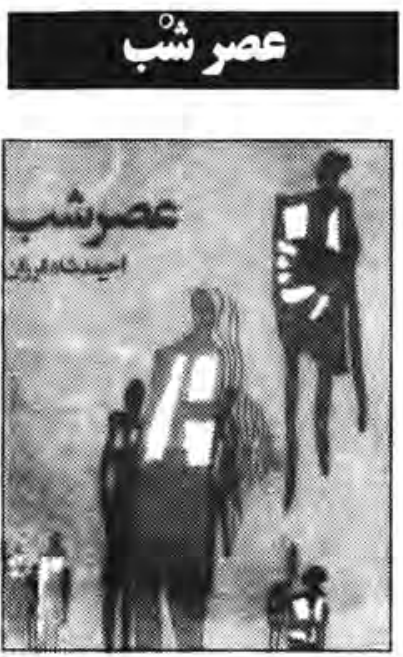

هـ جمو عه يداسبـان

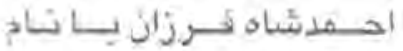

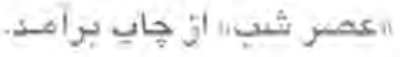
البـ

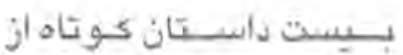

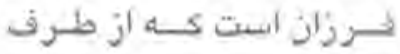

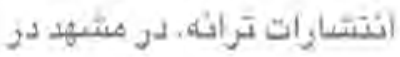

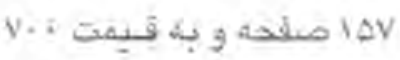
تو مان به خو انتئكان داستاي كوتاه عرضه شيده انست

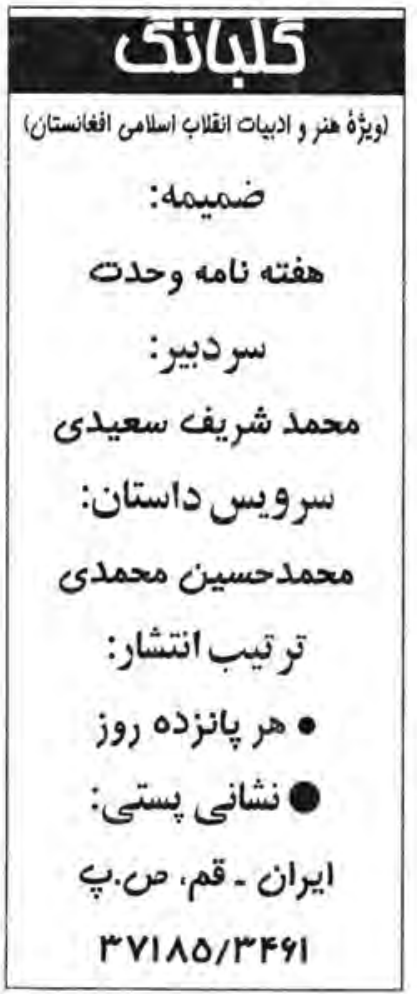

م شاعر كر انقدر جناب آقاى

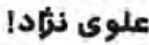

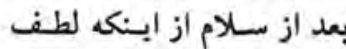

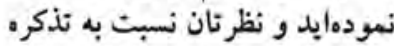

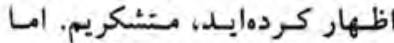

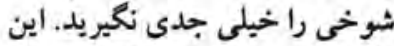

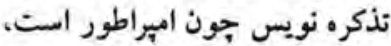
حرفهايى مىزند كه آدم بـ لرزه

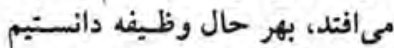

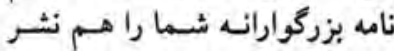
كنيب:

اجناب آتاى سـعيدى و دوستسان

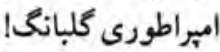

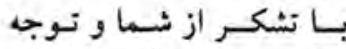

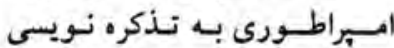

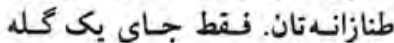
كوجى بـه كسوجكى تسمام زمسين

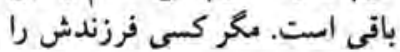

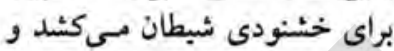

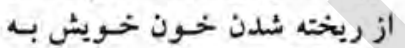

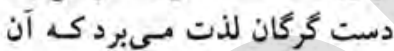

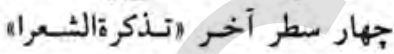

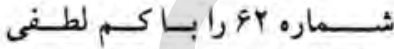

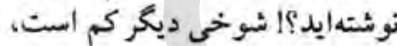

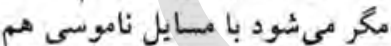

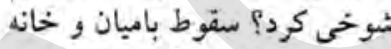
سوزى كاي فاجعه آميزيز آن كـدام

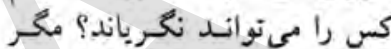
سقوط باميان نواميس ما را بازبجه يكران نساخت؟؟ و بحـر بـاميان

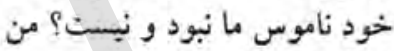
از طنزنويس امبراطور كـ دوبستم

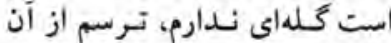

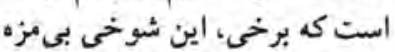

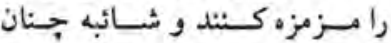

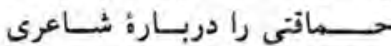
بزركوار(!) بيرورانند. و اين رباعى دراعي

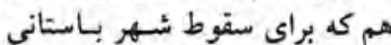

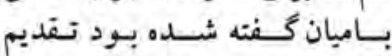

مىشود. اين همان نذر است:

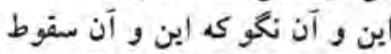
كريه كن زمين كه آسـمان مسفوط كرد كريه كن مزار زخميه، بريز اشك

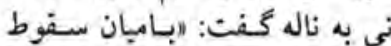
• ميدحيدر علوى نثرادها كر.2.

بسيار بسيار به خاطره نزديكى شده

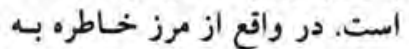

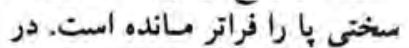

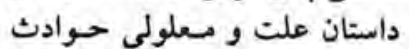

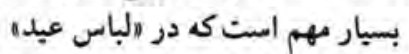

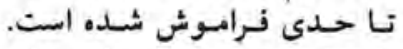

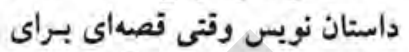

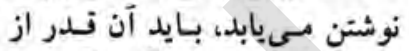

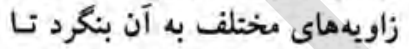

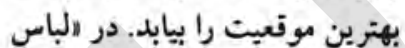
عيده موقعيث خوبى براي نسوشتن

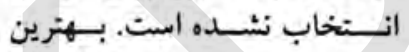

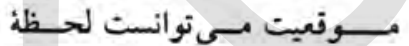
بـرخـورد راوى در روز عـيد بـان بجه هاى ديخر باشد. در واقع طرح درح

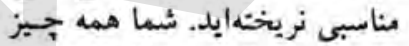
را شرح دادهايد، ولى داستان جاى نئل

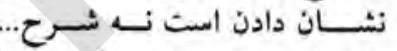

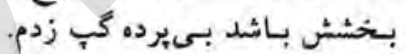

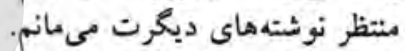
مي خواستم نقد جداءانهاي بـراي

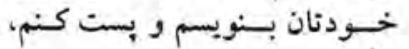

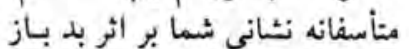
شدن باكت از بين رفنه بود.

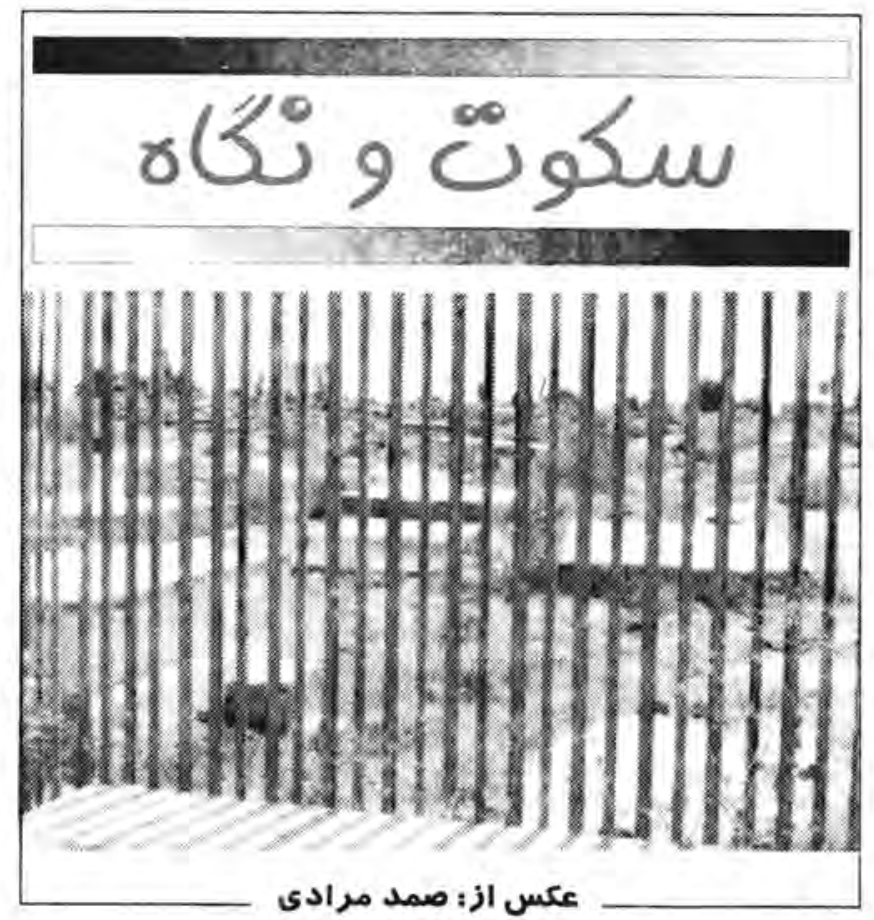

م برادر عزيز صببا سبيل نامه و مثنوى بلندت رئر وسيد. از اينكه به كمالات علم وهنر و خطن

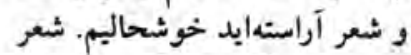
را جدىتر بحيريد واكر بتوانيد بـ ارين

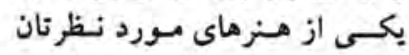
بيشتر بيردازيد مـوفقتر خـواهـيد

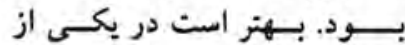
كرايشهايت ثاخص باشئ تا اينكه

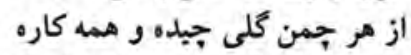

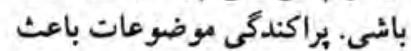

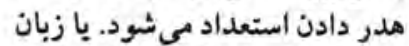
را جدى بكيريد يا خط را را يا شسعر را. تشخيص با خود شسماست. در ثـعر هـنوز در آغـاز راه هستيتد.

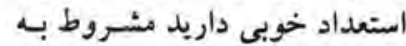

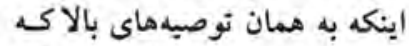

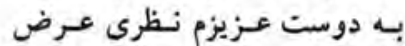
كردمام شها نيز توجه كنيد.

o عبدالواحد رفيعىاصفهان! در داستانوارة البـاس عـيده" نثرى روان و نـا حسدى داسـتانى داني

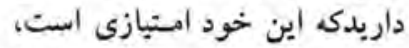

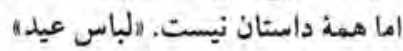

